\title{
Investigating Changes in Aeolian Sediment Transport at Coastal Dunes and Sand Trapping Fences: A Field Study on the German Coast
}

\author{
Christiane Eichmanns * and Holger Schüttrumpf (D) \\ Institute of Hydraulic Engineering and Water Resources Management (IWW), RWTH Aachen University, \\ Mies-van-der-Rohe-Straße 17, 52056 Aachen, Germany; schuettrumpf@iww.rwth-aachen.de \\ * Correspondence: eichmanns@iww.rwth-aachen.de
}

Received: 6 November 2020; Accepted: 7 December 2020; Published: 10 December 2020

\begin{abstract}
For the restoration and maintenance of beach and dune systems along the coast, knowledge of aeolian sediment transport and its interaction with coastal protection measures is required. As a nature-based solution, sand trapping fences can be an integral part of coastal protection measures initiating foredune development. There are few detailed studies on aeolian sediment transport rates on coastal dunes and sand trapping fences available to date. Thus, in this work, we present the results of field experiments conducted at the beach, coastal dune, and sand trapping fence on the East Frisian island Langeoog. The vertical sediment flux profile was measured by vertical mesh sand traps, and saltiphones measured the instantaneous sediment transport. A meteorological station was set up to obtain wind data. On the beach, dune toe, and dune crest, the stationary wind profile can be described well by the law of the wall. Saturated aeolian sediment transport rates on the beach and dune toe were predicted by widely used empirical models. Between the sand trapping fence, these empirical transport models could not be applied, as no logarithmic wind profile existed. The upwind sediment supply reduced after each brushwood line of the sand trapping fence, thereby, leading to increased deviation from the saturated conditions.
\end{abstract}

Keywords: aeolian sediment transport; wind flow; field experiments; nature-based solutions; sand trapping fences

\section{Introduction}

Coastal protection measures on the East Frisian Islands in the German North Sea generally involve coastal dunes, coastal dikes, and associated coastal protection structures [1,2]. The main roles of the coastal dunes on the East Frisian Islands are to provide flood protection for flood-risk areas against storm surges and to secure the existence of these islands [2-5]. These islands form a natural barrier system that reduces the wave energy during storm surges on the mainland coast in Lower Saxony. The islands are, therefore, maintained to reduce flood risks for the hinterland. The maintenance of the coastal dunes at the German North Sea coast generally involves sand nourishment at the coastal dunes, beach, and foreshore [2,6]. Over the past decades, sand nourishments have been an effective method for ensuring coastal protection of the island, to bridge temporary phases of sedimentary deficit caused by sandbar relocations [2,7]. The planting of vegetation and installing sand trapping fences to stabilize the natural dynamics of the dune system represent an additional component of coastal protection on the East Frisian Islands [8].

Nature-based solutions in coastal engineering such, as installing sand trapping fences aim to use natural processes and natural resources to contribute to coastal protection. Nature-based solutions are becoming increasingly popular due to the growing environmental awareness among the population, 
the increasing economic pressure on coastal areas, and the need for multidisciplinary approaches to meet the challenges of coastal protection. As natural processes can be a part of coastal protection measures, nature-based solutions could be a cost-effective alternative in the implementation of coastal infrastructure [7,9-11].

Sand trapping fences are widely installed along barrier islands to enhance the formation of foredunes after storm surges [12-14]. By installing sand trapping fences on the seaward dune slope close to the dune toe, the onshore wind velocity as well as the wind velocity parallel to the dune are reduced, and sediment can accumulate downwind and between the individual brushwood lines of a sand trapping fence. Using these sand trapping fences systematically, aeolian sedimentation processes can contribute to coastal protection by initiating and facilitating the establishment of the dune toe $[15,16]$.

Both natural as well as anthropogenically modified coastal dunes offer protection against storm surges and sea-level rising. Coastal dunes generally erode due to hydrodynamic forces during storm surges $[17,18]$. The process of dune erosion and wave-dune interaction is complex in terms of the highly dynamic interaction of soil and water but has been studied extensively in large-scale and small-scale flumes $[17,19-21]$, while the understanding of the preservation of coastal dunes, in general, is still limited $[7,22]$.

Coastal dunes grow predominantly due to aeolian sediment transport processes [23].Therefore, to support the restoration and maintenance of beach and dune systems, accurate knowledge of aeolian sediment transport processes and the effectiveness of coastal protection measures to strengthen coastal dunes is required $[3,22,24]$. Reliable prediction of sediment transport rates requires an understanding of the fundamental geomorphological processes causing changes in topography, aeolian ripple formation, aeolian ripple evolution, and saltation processes [25].

Generally, a good empirical knowledge of aeolian sediment transport rates in deserts exists [26,27]; however, the prediction of aeolian sediment transport rates in coastal areas is a major challenge due to the variety of influencing factors, such as the vegetation, moisture, wind force, and bed roughness [26,28-30]. Numerous authors have developed prediction models for saturated aeolian sediment transport rates for dry sand under equilibrium conditions in wind tunnel experiments $[23,27,31-34]$.

However, the aeolian sediment transport rates in wind tunnel experiments often differ from the measured sediment transport rates in the field $[22,27,35]$. The natural systems in coastal areas are very complex due to temporal-spatially changing conditions, which are generally neglected in most transport models, but strongly affect sediment transport rates $[7,27,28,36-39]$. In addition, to date there are few detailed studies available on aeolian sediment transport rates at different locations on the beach and/or in the coastal dunes [7,22]. In particular, the design of the sand trapping fences and their effect on aeolian sediment transport models have rarely been investigated [12,16,40].

Therefore, the objective of this work was to investigate the changes in aeolian sediment transport at coastal dunes and sand trapping fences. The five research goals were:

(1) Describing the wind profile, shear velocity, and aerodynamic roughness length for the beach, dune toe, and dune crest of the foredunes as well as before and between the sand trapping fence.

(2) Quantifying the vertical sediment flux profile for these measurement locations.

(3) Evaluating the performance of aeolian sediment transport models in comparison to the measured sediment transport rates under consideration of prevailing boundary conditions.

(4) Evaluating the downwind evolution of instantaneous sediment transport at these measurement locations.

(5) Describing the influence of sand trapping fences on aeolian sediment transport. 


\section{Study Site}

In Figure 1 the location of the study site in Germany (a) belonging to the federal state Lower Saxony as part of the East Frisian Islands (b) is shown. The study site in the northern part of the East Frisian island Langeoog (c) is shown in Figure 1d.
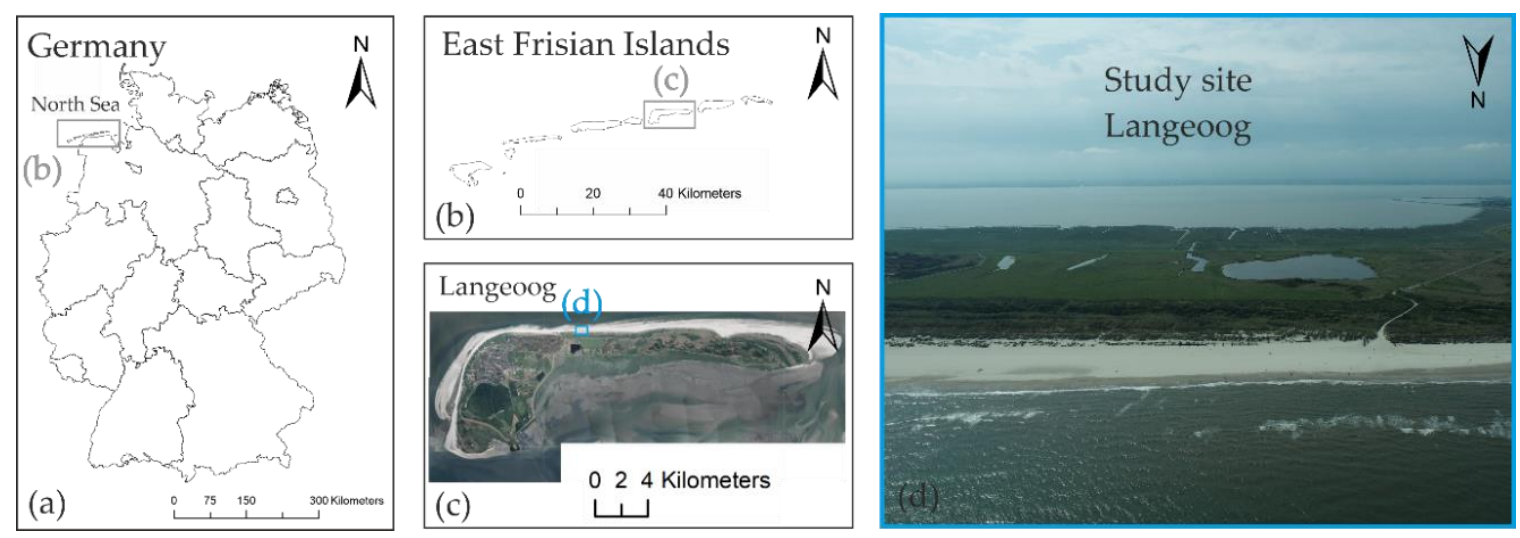

Figure 1. (a) Location of the study site in Germany (adapted from [41], with permission from (C) GeoBasis-DE/ BKG, 2020) belonging to the (b) East Frisian Islands, federal state Lower Saxony (adapted from [41], with permission from (C GeoBasis-DE/ BKG, 2020) as part of the (c) island Langeoog (adapted from [42] with permission from (C) dl-de/by-2-0, 2020), as well as the location of the (d) study site in the Northern part of Langeoog.

The East Frisian Islands are located in the German North Sea and form a barrier island system that developed in the Holocene. Seven permanently inhabited sandy barrier islands stretch over $\sim 90 \mathrm{~km}$ and are dissected by six main tidal inlets [2,6]. They are separated from the mainland (distance to mainland $\sim 3-20 \mathrm{~km}$ ) by a large muddy intertidal area with tidal flats. The Holocene sea level rise, the abundant sediment availability, large-scale embankments, and storm surges have contributed significantly to the development and shape of these barrier islands [43,44]. Up to now, the longshore migration of the intertidal sandbars in the coastal foreland from west to east in irregular periods of decades due to the tides, currents, wave loads, and storm surges caused a significant change in the sediment budget for the East Frisian Islands and resulted in a temporary supply or deficit of sand for these islands $[1,2,43,45]$.

The East Frisian island Langeoog covers an area of $\sim 20 \mathrm{~km}^{2}$ and has $\sim 20.3 \mathrm{~km}$ long coastal dunes stretching from the southwestern side of the island northward toward the east. No grey coastal protection structures are present. From the seaward side to inland, Langeoog's morphology consists of a natural sandy beach followed by foredunes and older dune landscapes with dunes up to $20 \mathrm{~m}$. In the southwest, Langeoog has extensively large areas with salt marshes [2,6,46,47].

Langeoog can be categorized as a mesotidal barrier island. Tides in this area are semi-diurnal with a tidal range of around $T_{R} \sim 2.7 \mathrm{~m}$ at the port entrance [47-49]. At each tidal cycle, the tidal basins with intertidal areas and supratidal salt marshes are filled and subsequently emptied [50]. The main wave direction is from southwest to northwest [51].

The climate is temperate [52] with an annual average temperature of $\sim 11{ }^{\circ} \mathrm{C}$ (Norderney, January 2015 to December 2019) and an annual average rainfall of $\sim 754 \mathrm{~mm}$ (Norderney, January 2015 to December 2019). The wind direction are mainly from southwest to northwest characterized by wind velocities up to $\sim 30 \mathrm{~m} / \mathrm{s}$ [53].

Figure 2 shows a close-up aerial photograph of the sand trapping fence. The sand trapping fence was installed from 18 May 2020 to 19 May 2020 by the Lower Saxony Water Management, Coastal Protection and Nature Conservation Agency and was made from locally available brushwood that was put into the sand and arranged in lines parallel and orthogonal to the coastal dune $[2,8]$. 
In Figure 2a, an aerial drone photograph and (b) a close-up of the sand trapping fence at the study site of Langeoog are shown.
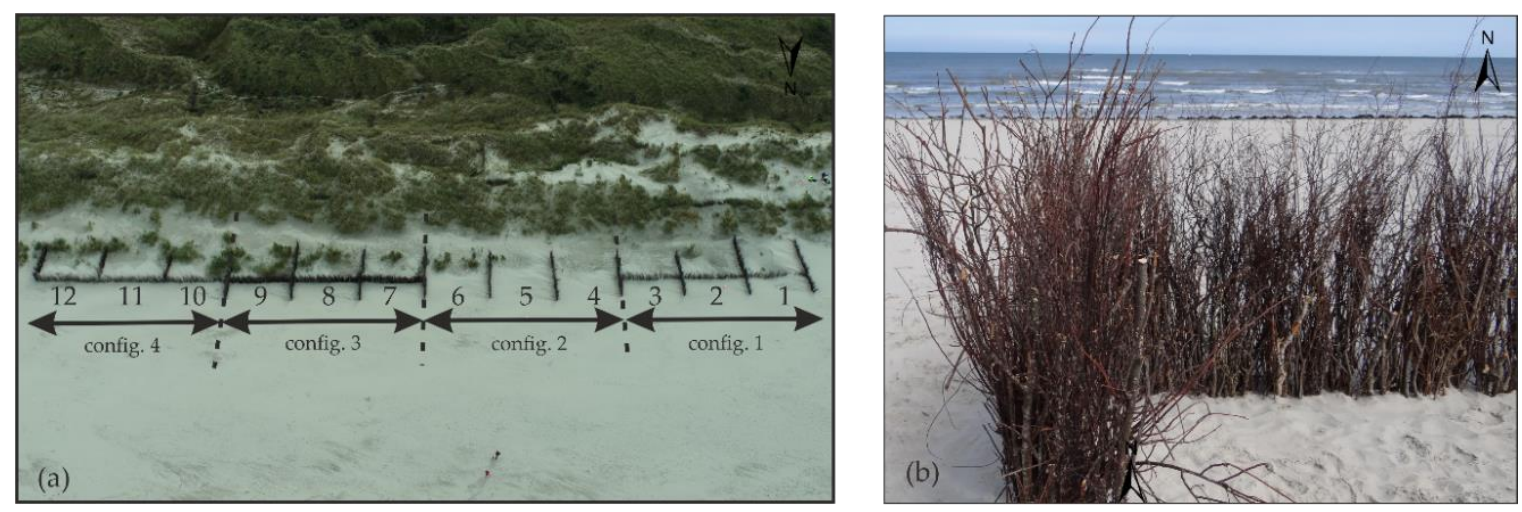

Figure 2. (a) Aerial drone photograph of the sand trapping fence with different configurations and (b) a close-up of the sand trapping fence consisting of brushwood on the study site of Langeoog (20 May 2020).

When the brushwood bushes were delivered, they were bundled by wires. As far as possible, the wires were removed from the bundles of brushwood. The investigations were conducted in front of field 1, in field 1, and in field 2 (all part of configuration 1). These fields were characterized by three bundles of brushwood per running meter orthogonal and two bundles of brushwood per running meter parallel to the coastal dune [54]. Currently, the design of the protruding brushwood height as well as the porosity of the sand trapping fences as well as their position in relation to the beach profile, and the length of the resulting fields between the sand trapping fences on the East Frisian Islands are based on empirical knowledge.

Figure 3 shows the top view of the study site with all four measurement locations: the beach, the area close to the dune toe, the area on the dune crest of the foredunes, and the sand trapping fence at the dune toe. The seaward side of the foredune is in part protected by a sand trapping fence.

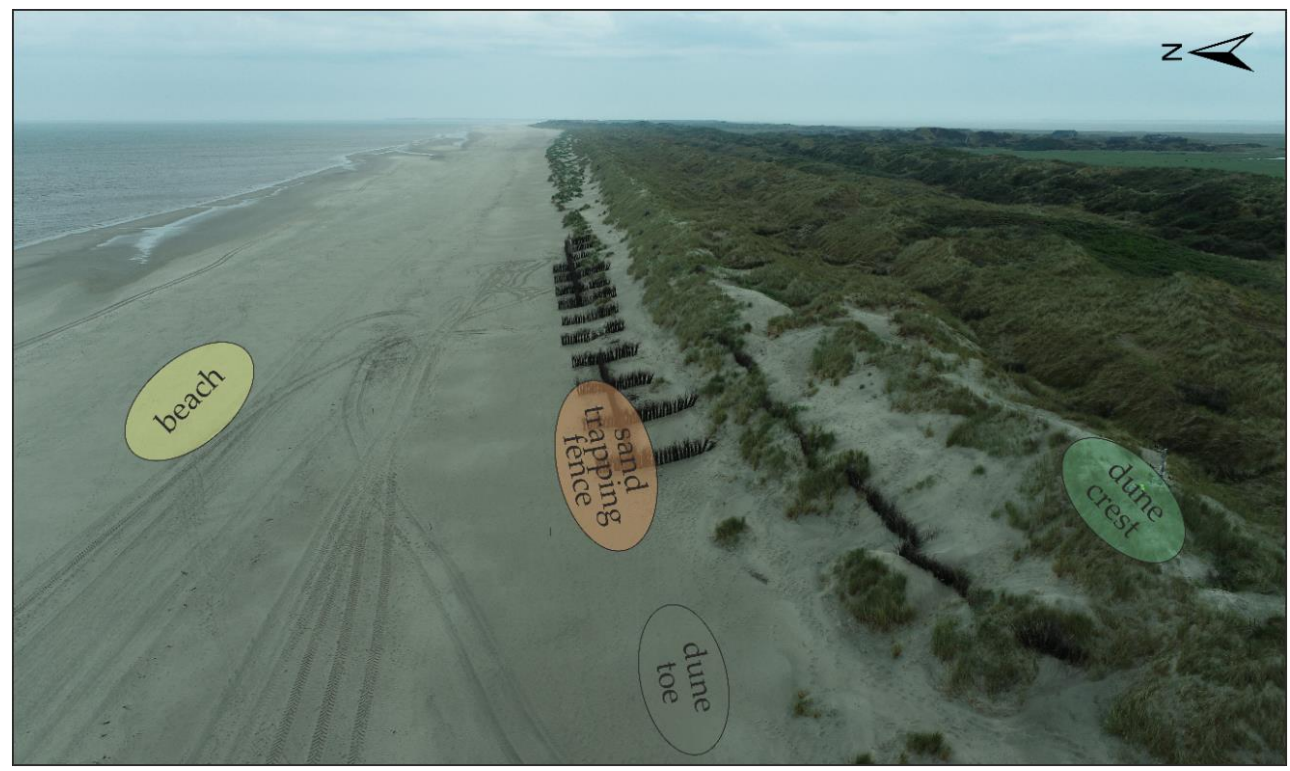

Figure 3. Overview of the different measurement locations: beach, dune toe, dune crest, and sand trapping fence at the study site Langeoog. The aerial photograph was obtained on 19 May 2020. 
All four measurement locations differ a lot in their prevailing boundary conditions. A closer visual impression of the locations (a) beach, (b) dune toe, (c) dune crest, and (d) sand trapping fence is given in Figure 4a.
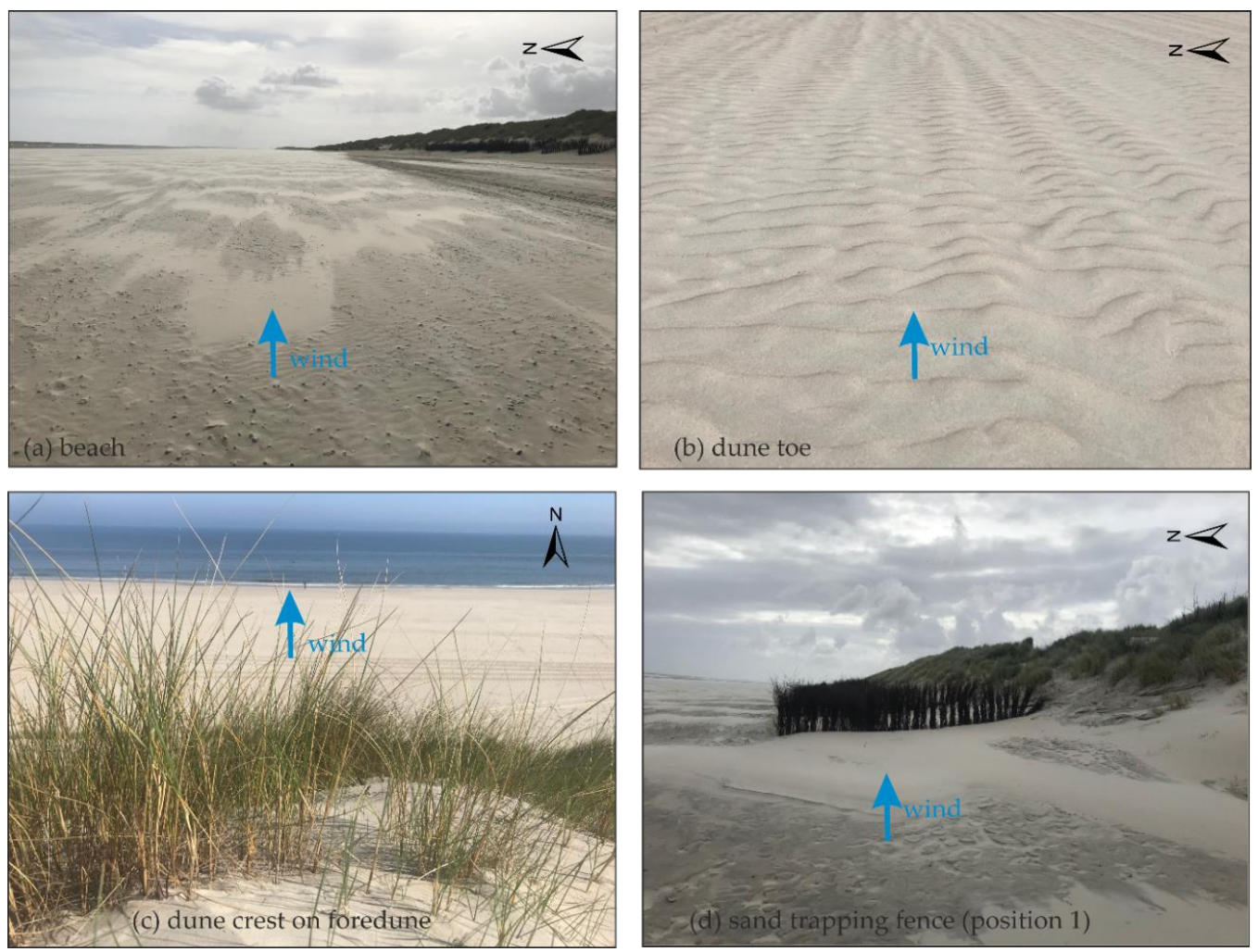

Figure 4. Closer visual impression of the measurement location at the (a) beach, (b) dune toe, (c) dune crest on the foredune, and (d) sand trapping fence (position 1) on Langeoog, Germany. Blue arrows indicate the respective wind direction during measurements at each measurement location.

For the measurement location beach, the sand was relatively wet $(M=7.08-10.38 \mathrm{Vol} \%)$. A few shell fragments were identified on the beach, see Figure $4 \mathrm{a}$. Close to the dune toe, the sand was relatively dry with a moisture content of maximum $M=1.8 \mathrm{Vol} \%$ and without shells or shell fragments, see Figure $4 \mathrm{~b}$. Many small sand ripples were recognized moving downwind. On the dune crest, dune grass of varying heights (with a medium height of about $0.5 \mathrm{~m}$ ) and irregularities in the topography of the dune crest area of about $2 \mathrm{~m}$ were present, see Figure 4c. In front of the sand trapping fence, sand was relatively wet with a maximum moisture value of $M=8.73 \mathrm{Vol} \%$. Sand was deposited in the form of a large, rippled sandbar, see Figure $4 \mathrm{~d}$, in front of the sand trapping fence. In the sand trapping fence, the moisture content of the sand varied between $M=1.80-8.90 \mathrm{Vol} \%$, and no sand ripples were present.

\section{Methodology}

\subsection{Experimental Setup and Instrumentation}

The field experiments began immediately after the completion of the installation of the sand trapping fence and were conducted from 19 May 2020 to 24 May 2020. They were focused on the aeolian transport processes and rates in correlation with the wind regime. The mean sediment transport rates were measured with three modified vertical mesh sand traps constructed according to Sherman et al. (2014) [55], covering a height of $z=0.3 \mathrm{~m}$ above the surface, see Figure 5a. The vertical mesh sand traps consisted of six rectangular aluminium tubes arranged one above the other. Each rectangular aluminium tube was $b=0.1 \mathrm{~m}$ wide, $h=0.05 \mathrm{~m}$ high, and $l=0.25 \mathrm{~m}$ long, with edges $e=2 \mathrm{~mm}$ thick. 
To enable sand to be trapped, each tube was covered with a bag made of nylon mono filament with openings of size $=50 \mu \mathrm{m}$. A long nylon bag $l=0.75 \mathrm{~m}$ was used for the lowest tube, for all other heights the nylon back was $l=0.5 \mathrm{~m}$ long. A threaded rod and rubber bands fixed the nylon bags to the frame. This design of the vertical mesh sand traps was used in field experiments by Campos (2018) [56]. It is a cost effective measurement tool with good efficiency results [55].
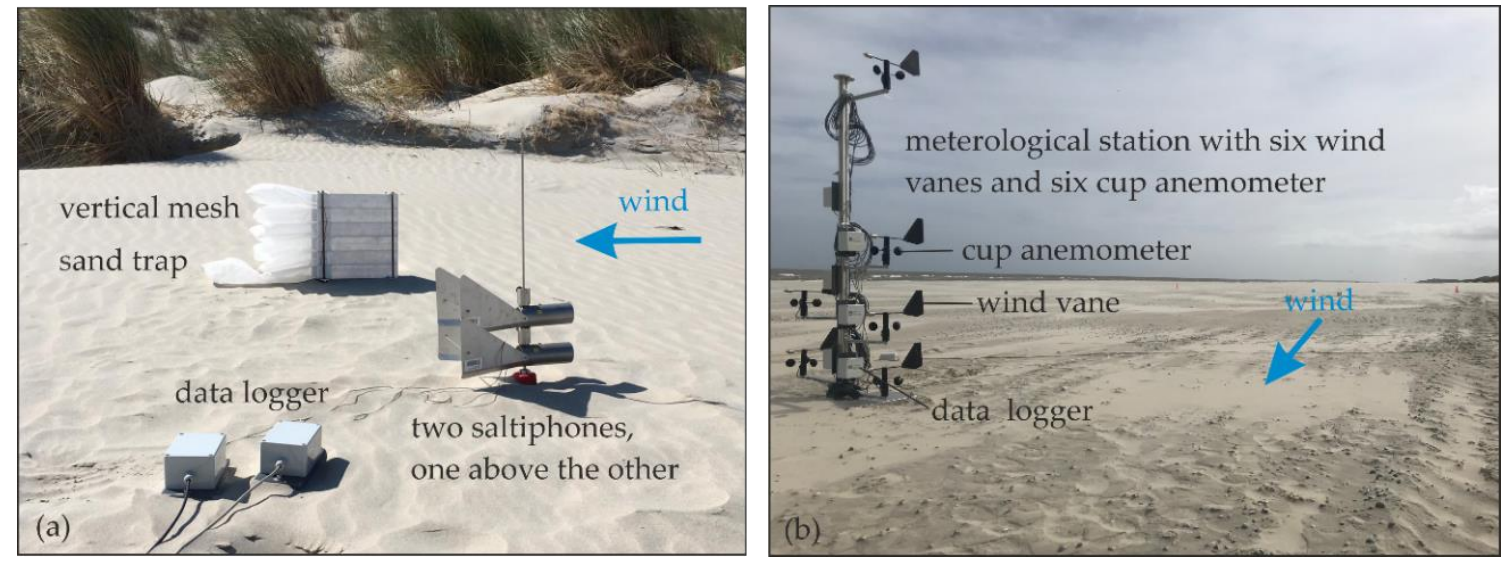

Figure 5. Measuring equipment at the beach of Langeoog, Germany, during the field campaign on 23 May 2020. (a) Modified vertical mesh sand trap as well as an array of two saltiphones with respective data loggers, (b) meteorological measuring station with six cup anemometers, six wind vanes, and six data loggers. Blue arrows indicate the respective wind direction during measurements.

Six saltiphones from the company Eijkelkamp, see also Figure 5a, were used to measure the instantaneous sediment transport. The saltiphones consist of a microphone, installed in a stainless-steel housing. Each sediment grain hitting the microphone is counted. The maximum cumulative number of impacts per second is generally limited to 1000 . The overall measurement accuracy is given with $5 \%$ [57]. The data of the saltiphones were recorded by a data logger that was built by the IWW. Two wind vanes on the back of the tube ensured that the microphone was positioned in the wind direction. The saltiphones were calibrated by checking that all six saltiphones gave nearly the same amount of counted grains hitting the microphone for a defined sediment probe. For this purpose, a weighed mass of quartz sand was poured into the housing of each saltiphone at a defined distance. Detailed information about the principle of saltiphones is given by Spaan and van der Abeele (1991) [58] and Goossens et al. (2018) [59].

In this field campaign, a total of three saltiphone stations, each station consisting of two saltiphones, were used. They were placed in such a way that the centre of the microphones was arranged at $z=0.05 \mathrm{~m}$ and $z=0.15 \mathrm{~m}$ above the bed surface. Thereby, the instantaneous sediment transport at different altitudes could be estimated. However, in weak wind conditions, it can be possible that the transport layer is so low that most particles pass underneath the lowest sensor [22].

A meteorological station, see also Figure $5 b$, was set up to obtain the wind velocity and wind direction at the study site.

The sensors OMEGA WMS-23 consisted of a cup anemometer to register the wind velocity and a wind vane to measure the wind direction relative to north. The wind sensors were mounted on a vertical bar at predefined heights of $z=0.13,0.17,0.45,0.59,0.91$, and $1.95 \mathrm{~m}$ and the wind vanes were at $0.24,0.28,0.56,0.70,1.02$, and $2.06 \mathrm{~m}$, respectively. The wind data were recorded with a measuring rate of $f=10 \mathrm{~Hz}$. The measuring accuracy of the wind vane is stated with $\pm 3^{\circ}$ and for the wind anemometer it is the larger value of $\pm 3 \%$ or $0.45 \mathrm{~m} / \mathrm{s}$ [60].

An unmanned aerial vehicle (UAV, manufacturer DJI Phantom 4 with real time kinematics) was used to obtain ortho-image data, which was referenced by four ground control points. Ortho-images taken by the drone achieved an accuracy of $1 \mathrm{~cm}+1$ parts-per-million (ppm) of distance between the 
rover and base horizontally and $1.5 \mathrm{~cm}+1 \mathrm{ppm}$ of distance between the rover and base vertically [61]. The exact position of all measuring equipment and reference points were registered additionally using a global navigation satellite system JAVAD GNSS Receiver SigmaD with the same accuracy horizontally and vertically as the drone [62].

A sedimentological analysis according to the specifications in ISO 17892-4 [63] was conducted to determine the grain size distribution at the study site. The spatially variable moisture contents at the vertical mesh sand traps, at the saltiphones, and at the meteorological station were measured by a moisture content sensor Theta-Probe ML3 to quantify the volumetric water content of the sand up to $6 \mathrm{~cm}$ beneath its surface [64].

In Figure 6, an aerial photograph of the measurement locations with the instrumental setup is shown. For all measurement locations, except for the dune crest, the same measuring equipment was used. On the dune crest, no sediment transport took place during the conducted experiments; thus, only wind velocity and wind direction were measured at this location. The windblown sand grains were recorded with three saltiphone measuring stations and three vertical mesh sand traps. For the beach and the dune toe, the wind tower was placed $1.0 \mathrm{~m}$ windward to the left, and the vertical mesh sand traps were placed $0.5 \mathrm{~m}$ windward to the right of the saltiphones.

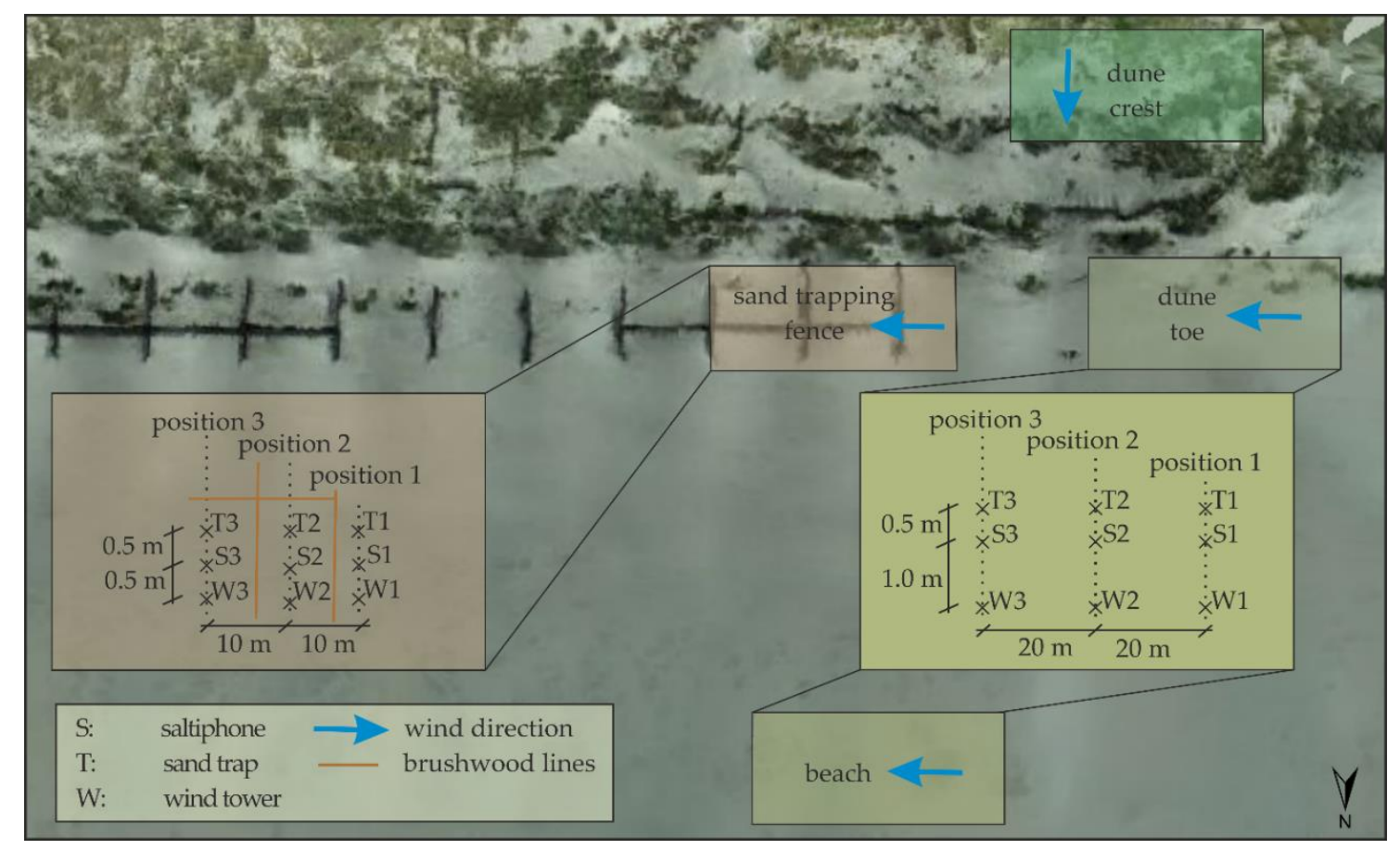

Figure 6. Aerial photograph for the measurement locations: beach, dune toe, dune crest (no sediment transport), and sand trapping fence with the arrangement of the vertical mesh sand traps, the saltiphones, and the wind towers. Blue arrows indicate the respective wind direction during measurements at each measurement location.

The distance between each measuring position was $20 \mathrm{~m}$. The arrangement of the instrumentation for the sand trapping fence differed with regard to Figure 6. Between the brushwood lines of the sand trapping fence the distance between wind tower and saltiphone was reduced to $0.5 \mathrm{~m}$, and the distance between the individual positions was reduced to $10 \mathrm{~m}$. The measuring location sand trapping fence, position 1, was located close to the dune toe in front of the sand trapping fence windward, where the wind was not yet influenced by the brushwood lines. In field 1 (position 2) and field 2 (position 3 ) the wind regime was influenced by the brushwood lines under the prevailing wind conditions from west during the experiments. 
Every $20 \mathrm{~min}$, the wind tower was moved to the next measuring position. Meanwhile, the saltiphones and vertical mesh sand traps remained at their initial location. This procedure was repeated between three and five times starting at the first position again.

\subsection{Analysis Method}

\subsubsection{Wind Velocity, Shear Velocity, and Aerodynamic Roughness Length}

Saturated aeolian sediment transport rates can be described by sediment transport models as a function of the shear velocity $[7,22,23,25,28,65]$. In most models, it is assumed that the sand is dry, the wind velocity and the sediment transport rates are steady and a logarithmic velocity profile over a flat surface is developed [37,55].

In our data set, the wind velocity profile was measured by six cup anemometers at predefined heights. An appropriate averaging time must be selected to gain reliable values for the shear velocity and aerodynamic roughness length. To account for larger boundary layer turbulences at higher altitudes, averaging over longer time scales is required [66]. However, the potential to choose shorter averaging time scales has been recognized when the highly variable aeolian sediment transport is the focus of investigation. As many researches stated [25,65,67], short averaging time scales ( 10 s) allow for resolving short-term variations in surface roughness and aeolian sediment transport due to changing wind conditions. For example, Strypsteen et al. (2019) [22] and Ellis et al. [68] (2009) chose time scales for averaging of less than $1 \mathrm{~min}$. In this study, $10 \mathrm{~s}$ as the averaging time scale was chosen.

The obtained wind data were filtered. As a criterion for valid wind measurement data, gusts defined by the German Weather Service were excluded. Therefore, the measured wind velocity must not exceed the measured 10-min average wind velocity by at least $5.0 \mathrm{~m} / \mathrm{s}$ in a time interval greater than $3 \mathrm{~s}$ and smaller than $20 \mathrm{~s}$ [53]. To obtain stationary wind profiles, the following conditions were defined: The coefficient of variance of each 10-second-interval at each measurement point must not exceed the selected maximum value of $v \leq 0.15$ and the gradient of acceleration of two successive wind profiles over the selected time interval at each measurement point must not be greater than $b \leq 0.5 \mathrm{~m} / \mathrm{s}^{2}$.

Under neutral atmospheric stability conditions, the wind velocity distribution over the viscous sub boundary layer for aerodynamically rough surfaces can be described [23] with the law of the wall as follows:

$$
u_{z}=\frac{u_{*}}{\kappa} \cdot \ln \frac{z}{z_{0}},
$$

where $u_{z}[\mathrm{~m} / \mathrm{s}]$ is the wind velocity at height $z$ [m], $\mathrm{k}$ [-] is the Kármán constant (here: 0.41$), u^{*}[\mathrm{~m} / \mathrm{s}]$ is the shear velocity, and $z_{0}[\mathrm{~m}]$ is the aerodynamic roughness length $[69,70]$.

The parameters $u^{*}$ and $z_{0}$ were determined from experimental data through a regression analysis of the measured wind velocities at defined heights over the selected time interval of $10 \mathrm{~s}$. A least-square fit of the wind velocities $u[\mathrm{~m} / \mathrm{s}]$ to the natural logarithm of the wind measurement height $\ln (z)$ was applied. The shear velocity $u^{*}[\mathrm{~m} / \mathrm{s}]$ results from the slope of the regression line of $u[\mathrm{~m} / \mathrm{s}]$ on $\ln (z)$ multiplied by the Kármán constant $\kappa$ [-]. The aerodynamic roughness length is equal the exponential function of the following term: the quotient of the negative $y$-axis interception and the slope of the regression line $u[\mathrm{~m} / \mathrm{s}]$ on $\ln (z)[25,65,71]$. Only wind profiles that had a coefficient of determination greater than $R^{2}>0.90$ were retained for further analysis to ensure only stationary logarithmic wind profiles were analyzed in the following.

With increasing drag and lift force on the particle, there is a critical value at which grain movement is initiated. In nature, this depends on the surface moisture, surface roughness, vegetation, shells, surface slope, and fetch effect $[7,35,39,72,73]$. The so-called critical shear stress $u^{* t}$ is defined as [18]:

$$
u^{* t}=\mathrm{A} \cdot \sqrt{\left(\frac{\rho_{s}}{\rho_{a}}-1\right) \cdot \mathrm{g} \cdot d_{50}}
$$


where A [-] is an empirical constant, $\rho_{a}\left[\mathrm{~kg} / \mathrm{m}^{3}\right]$ is the density of air (here: $1.2 \mathrm{~kg} / \mathrm{m}^{3}$ ), and $\rho_{s}\left[\mathrm{~kg} / \mathrm{m}^{3}\right]$ is the density of sand grains (here: $2650 \mathrm{~kg} / \mathrm{m}^{3}$ ). The gravitational acceleration is given with $\mathrm{g}\left[\mathrm{m} / \mathrm{s}^{2}\right]$ (here: $9.81 \mathrm{~m} / \mathrm{s}^{2}$ ), and $d_{50}[\mu \mathrm{m}]$ is the mean particle size (here: $210 \mu \mathrm{m}$ ). The empirical constant is assumed as $\mathrm{A}=0.11$. This value takes into account the effect of cohesion, but not the influence of the protective layer of shells or the increasing cohesion due to higher moisture contents [74-76]. With the given parameters, the critical shear velocity at the study site of Langeoog was calculated as $u^{* t}=0.24 \mathrm{~m} / \mathrm{s}$.

\subsubsection{Vertical Sediment Flux Profile and Potential Aeolian Sediment Transport Rates}

The vertical mesh sand traps, see also Figure $5 \mathrm{a}$, were exposed to sediment flow during a defined exposure time, and, afterward, the collected sand was weighed and divided by the inlet area and measurement duration to calculate the mean sediment flux rate. The vertical distribution of sediment transport can be described by an empirical exponential decay function $[22,68,77]$ :

$$
q_{z}=q_{0} \cdot \exp (-\beta \cdot z)
$$

where $q_{z}\left[\mathrm{~kg} / \mathrm{m}^{2} / \mathrm{s}\right]$ is the sediment transport rate at a predefined height $z[\mathrm{~m}], q_{o}\left[\mathrm{~kg} / \mathrm{m}^{2} / \mathrm{s}\right]$ is the extrapolated saltating sediment mass transport at the surface, and the decay rate $\beta[1 / \mathrm{m}]$ as a measure of the vertical concentration gradient. $\beta$ and $q_{0}$ can be obtained by a regression analysis to the data of the field experiments [78]. The regression provides generally high correlations of the coefficients, as they are only weakly related to physical aeolian parameters, such as grain size, roughness, and shear velocity. Therefore, a wide range of fitted coefficient values can be found in literature [22,78].

The total mass transport can be calculated by integrating Equation (3) as follows:

$$
Q_{s}=\int_{0}^{\infty} q_{z} d z=\frac{q_{0}}{\beta}
$$

where $Q s[\mathrm{~kg} / \mathrm{m} / \mathrm{s}]$ is the total mass transport by saltation. It is assumed that saltating particles start moving immediately above the surface $(z=0 \mathrm{~m})$ [78].

In Table 1, five representative sand transport models related to the shear velocity $u^{*}[\mathrm{~m} / \mathrm{s}]$, used to calculate the saturated aeolian sand transport rates $Q s[\mathrm{~kg} / \mathrm{m} / \mathrm{s}]$ for dry sand, are given. For an overview of all existing models, reference is made to Dong et al. (2003) [79] and Strypsteen (2019) [22]. With the exception of wind velocity, all parameters are considered to be constant over time. $C_{i}[-]$ are constants derived by wind tunnel and/or field experiments from different authors. $D$ (here: $250 \mu \mathrm{m}$ ) [29] is the reference diameter of the sediment as a standard value for dune sand.

Table 1. Summary of five chosen representative sand transport models for predicting saturated aeolian sand transport rates for dry sand (modified after [22,79]).

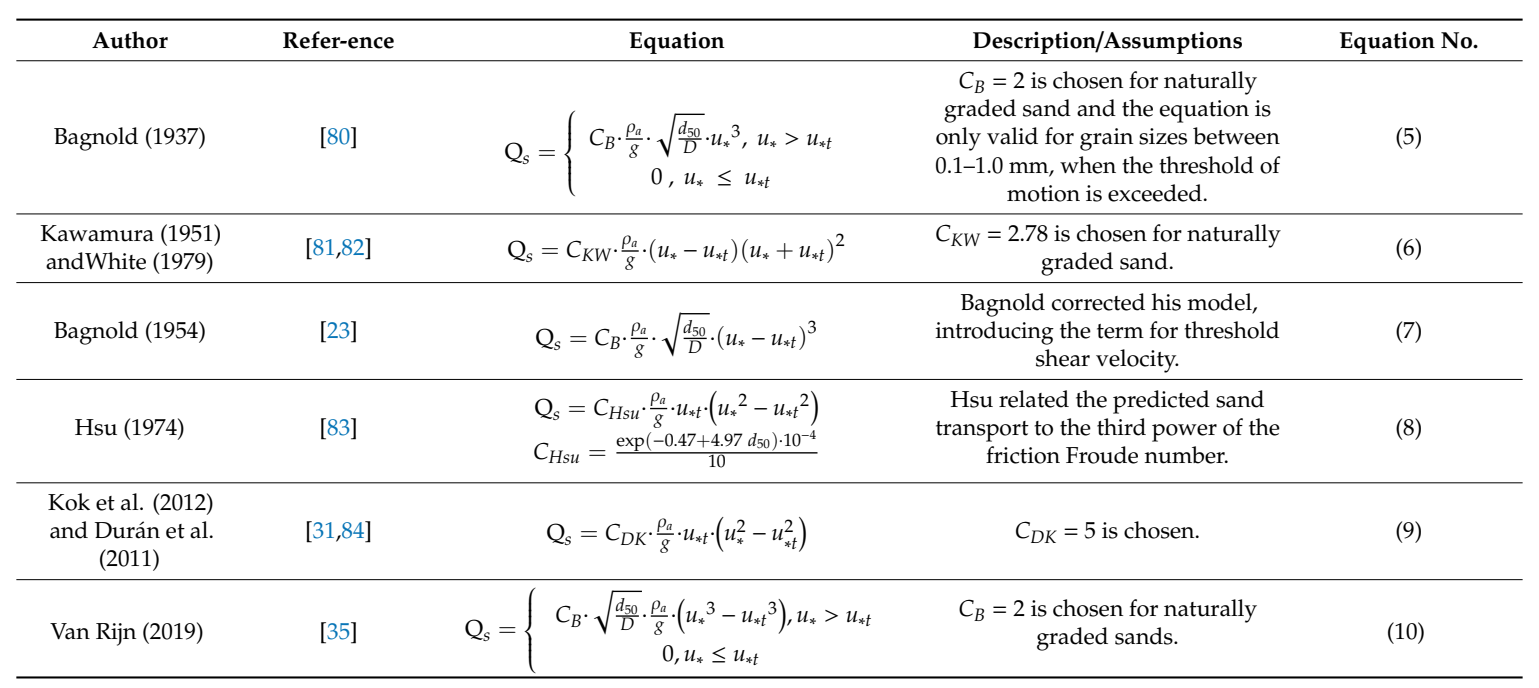


The moisture content on a beach is subject to large spatial and temporal variations $[35,36,39]$. With increasing moisture content, the cohesion between the sand particles rises; therefore, the critical shear velocity is increased. Even low moisture contents ( $\mathrm{M} \sim 0.5 \mathrm{Vol} \%$ ) can reduce the transport rates significantly, except when the wind velocity is intense. Saturated moisture content can reduce the instantaneous transport rate by a factor of $m_{\text {moisture }}=2-10[30,36,38,76]$. Therefore, to predict the sediment transport of wet sand the following equation is used:

$$
Q_{s, \text { wet }}=\frac{Q_{s, d r y}}{m_{\text {moisture }}}
$$

where $Q_{s, \text { wet }}[\mathrm{kg} / \mathrm{m} / \mathrm{s}]$ is the predicted transport rate for wet sand, and $Q_{s, d r y}[\mathrm{~kg} / \mathrm{m} / \mathrm{s}]$ is the saturated aeolian sand transport rates for dry sand.

\section{Results and Discussion}

According to the conducted sieve analyses, the median grain size $D_{50} \sim 218 \mu \mathrm{m}$ was chosen as an average value for the measurement locations of the beach, dune toe, and sand trapping fence. The sieve analyses results from the measurement location of the dune crest were excluded for determining the median grain size as no sediment transport was measured on the dune crown. For more details regarding grain size distribution, $d_{10}$ and $d_{90}$ are also provided representing the grain sizes for $10 \%$ and $90 \%$ sieve retainment: $D_{10} \sim 150 \mu \mathrm{m}, D_{90} \sim 302 \mu \mathrm{m}$. The mean size was equal to $D_{m} \sim 209 \mu \mathrm{m}$, and the standard deviation was $\sigma \sim 212 \mu \mathrm{m}$.

During the whole field campaign, the sand at the study site was almost continuously slightly wet with varying moisture contents around an average value of $M=6 \mathrm{Vol} \%$ up to a maximum moisture content of $M=14.5 \mathrm{Vol} \%$ (average values for all locations). The weather was sunny with a maximum temperature of $T=18{ }^{\circ} \mathrm{C}$. The wind was strong over the selected 10-second-interval with an average wind velocity around $u_{2}=16.6 \mathrm{~m} / \mathrm{s}$ at a height of $z=2.0 \mathrm{~m}$ up to stormy conditions with a maximum of $u_{2}=24.7 \mathrm{~m} / \mathrm{s}$. The wind direction came mainly from the west, which lead to coast parallel sediment transport. Aeolian sand transport occurred in the form of streamers. The average shear velocity was almost always above the threshold of movement of $u^{* t}=0.24 \mathrm{~m} / \mathrm{s}$ based on Equation (2). However, aeolian sediment transport was not measured throughout the whole field campaign.

\subsection{Wind Velocity Profiles, Shear Velocities, and Aerodynamic Roughness Length}

In this Section 4.1, the typical results of the measured velocity profiles and corresponding regression lines to determine the shear velocity and the roughness length for the four different measurement locations, the beach, dune toe, dune crest, and between the sand trapping fences at the study site, are presented. In Figure 7, the wind profiles to determine the shear velocity and roughness length parameters for the locations (a) beach and (b) dune toe are shown. The blue dots show the measured wind velocity at a predefined elevation, the arrows show the wind direction-in this example, the wind comes from the west, and the red line shows the regression line. 

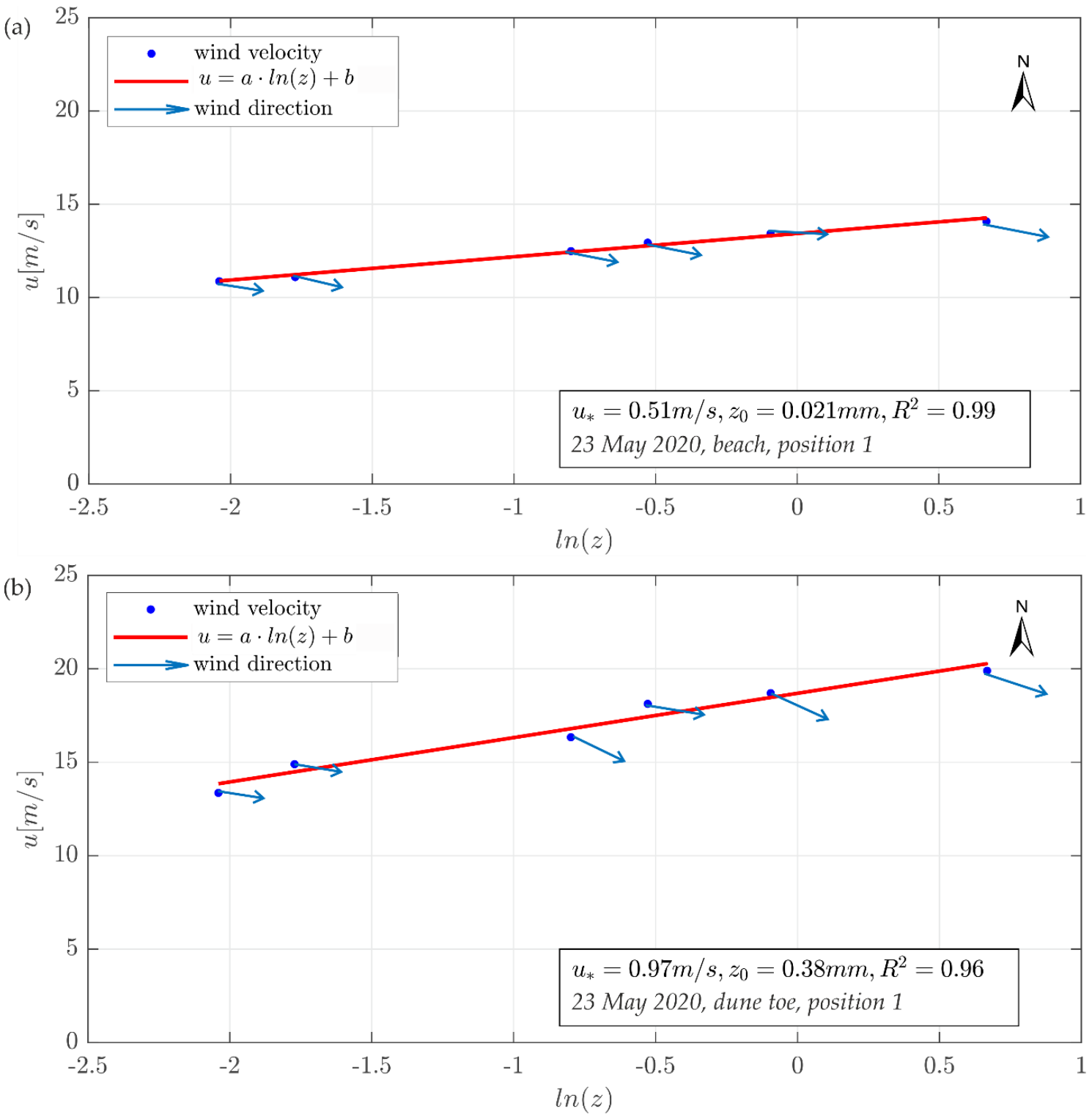

Figure 7. Representative example of a velocity profile for the locations (a) beach and (b) dune toe on the study site of Langeoog. The blue dots show the measured wind velocity, the blue vectors show the wind direction, and the red line indicates the regression line, see Equation (1).

The regression for all evaluated wind data fits the location beach and dune toe well with an overall coefficient of determination of $R^{2}=0.95\left(u^{*}=0.93 \mathrm{~m} / \mathrm{s}\right)$ and $R^{2}=0.88\left(u^{*}=0.43 \mathrm{~m} / \mathrm{s}\right)$. The lower coefficient of determination of the regression at the dune toe can be explained by the larger unevenness in the topography compared to the beach. Thereby, it is proven for the locations of the dune toe and beach that the wind profile can be displayed appropriately by the law of the wall, see Equation (1).

In Figure $8 \mathrm{a}$, the wind profile for the location dune crest and, in Figure $8 b$, the wind profile for the location sand trapping fence in field 1 (position 2) are shown. Regression analyses for position 1 and position 3 were evaluated, but are not shown in the following Figure 8. 

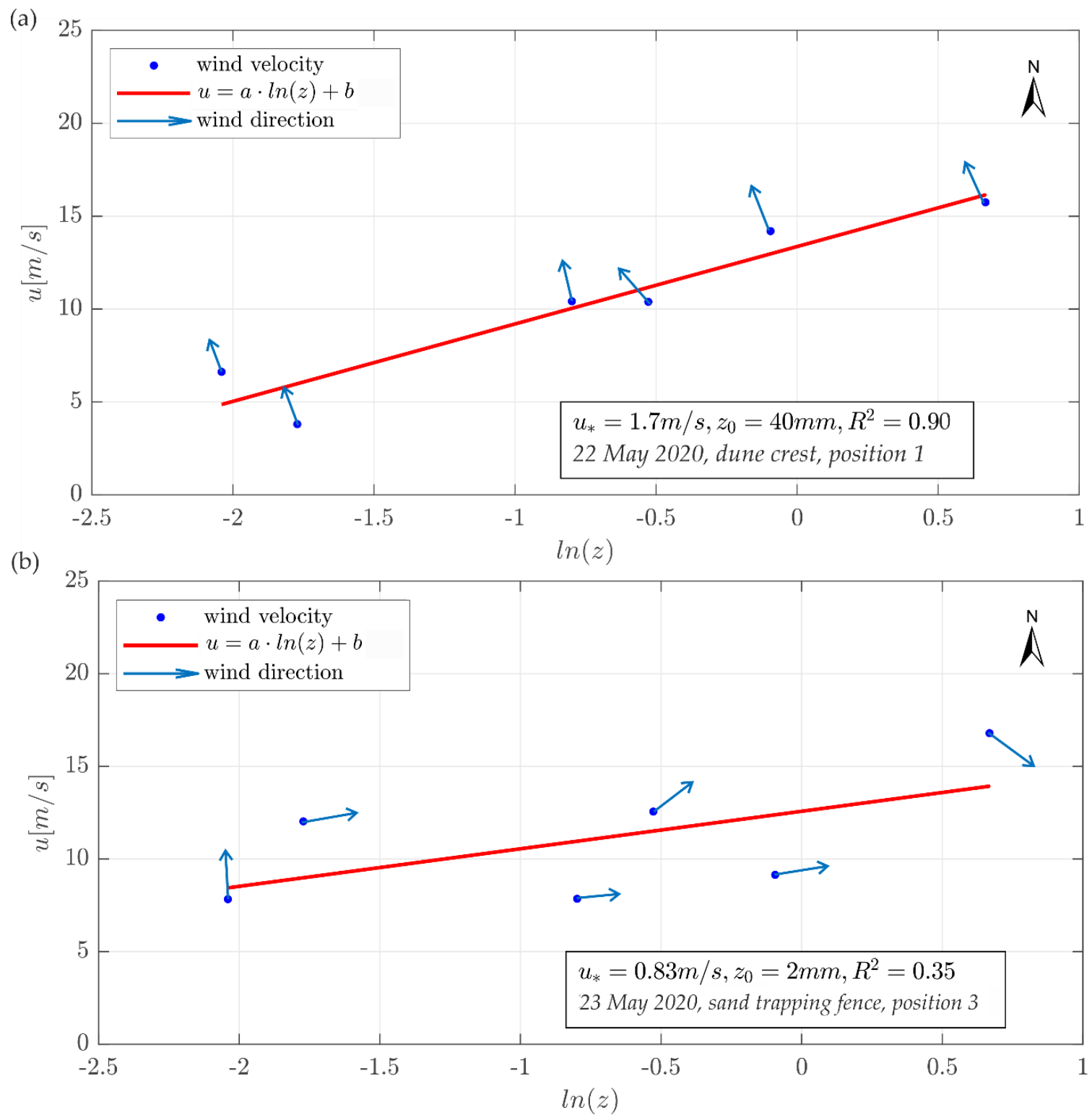

Figure 8. Representative example of a velocity profile to determine the shear velocity and roughness length for the locations (a) dune crest and (b) sand trapping fence (position 2) on the study site of Langeoog. The blue dots show the measured wind velocity, the blue vectors show the wind direction, and the red line indicates the regression line, see Equation (1).

The regression analysis of all wind data fit the measuring points for the location dune crest on the foredunes with an overall determination coefficient of $R^{2}=0.82\left(u^{*}=0.65 \mathrm{~m} / \mathrm{s}\right)$. Due to the strong wind, the dune grass bent on the coastal dune to varying degrees depending on the wind velocity, resulting in different roughness lengths. Even with the same vegetation cover and height, the wind flow characteristics can be different [85]. In front of the sand trapping fence at position 1, see also Figure 6, the overall coefficient of determination was $R^{2}=0.89\left(u^{*}=0.92 \mathrm{~m} / \mathrm{s}\right)$. The measuring location of the sand trapping fence, position 1, was located close to the dune toe in front of the sand trapping fence windward, so that the wind was not yet influenced by the sand trapping fence.

Between the sand trapping fence at location 2 and location 3, the overall coefficient of determination was significantly lower with $R^{2}=0.34$ and $R^{2}=0.38$, respectively. On the basis of the curve fitting, between the sand trapping fence, no stationary logarithmic velocity profiles were present. In between the sand trapping fence, the wind directions and the wind velocities varied considerably, see also the 
wind vectors in Figure $8 \mathrm{~b}$. We assumed that turbulent fluctuations took place $[16,86]$, and therefore the effects of short-time variations in the surface roughness associated with large eddies cannot be displayed appropriately by a one-dimensional wind profile according to Equation (1).

In Figure 9, the relationship between the calculated shear velocity $u^{*}[\mathrm{~m} / \mathrm{s}]$ and the aerodynamic roughness length $z_{0}[\mathrm{~mm}]$ at the different measurement locations are shown. The black line indicates the regression for the beach, dune toe, and sand trapping fence (position 1) with the following equation:

$$
z_{0}=\mathrm{a} \cdot u_{*}^{b}
$$

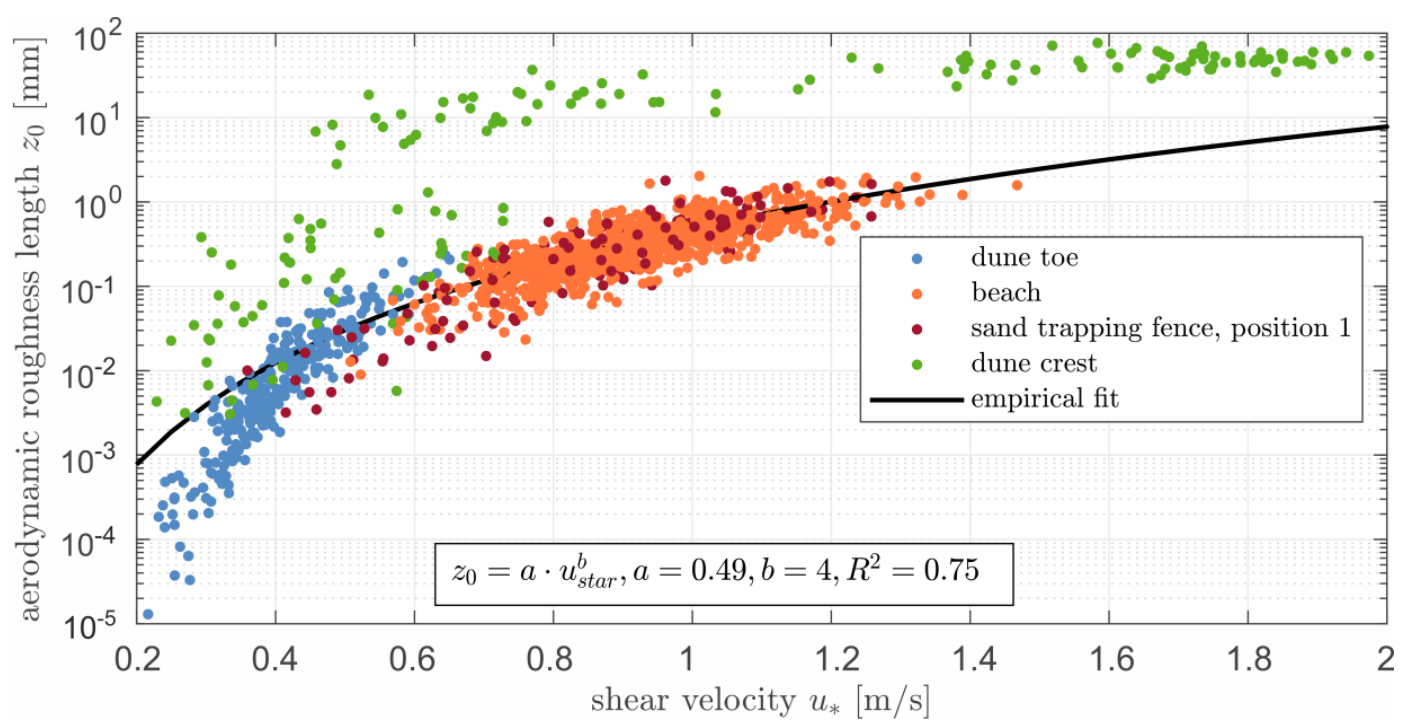

Figure 9. Regression line for the calculated shear velocity and aerodynamic roughness length for the measurement locations of the dune toe, beach, and sand trapping fence (position 1) and calculated aerodynamic roughness length for the location dune crest (not part of the regression).

The regression parameters are defined as $a=0.49$ and $b=4$ with a determination coefficient of $R^{2}$ $=0.75$. The dune crest data is not implemented in the regression line.

The values for the aerodynamic roughness length close to the dune toe lie between $z_{0}=2.6 \cdot 10^{-6}-0.23 \mathrm{~mm}$, on the beach $z_{0}=0.009-2.03 \mathrm{~mm}$, and in front of the sand trapping fence between $z_{0}=0.003-1.79 \mathrm{~mm}$. The results of the dune crest cannot be compared directly to the results of the dune toe, beach, and sand trapping fence (position 1) due to the presence of vegetation and higher bed roughness on the dune crest (see also Section 2). At the dune crest, the values were significantly higher ( 100 times) and were subject to more scatter with aerodynamic roughness lengths of around $z_{0}=0.003-90.96 \mathrm{~mm}$. However, they follow the same trend as the measurement locations of the dune toe, beach, and sand trapping fence (position 1). The values are in a similar range as other field experiments for estimating the aerodynamic roughness length over a coastal dune field [85].

The aerodynamic roughness length increased with the increasing shear velocity. The aerodynamic roughness length increased as a power law with the increasing shear velocity [22,25].

\subsection{Vertical Sediment Flux Profile}

For the measurement locations of the beach, dune toe, and sand trapping fence (position 1 and position 2), the vertical mesh sand traps over $z=0.3 \mathrm{~m}$ above the surface were analyzed in the following. In Figure 10, a representative example of the vertical distribution of sediment transport fluxes derived from the vertical mesh sand traps is shown for the measurement location of the beach. The trapped sediment over the height is described using an exponential decay curve as described in Equation (3). 


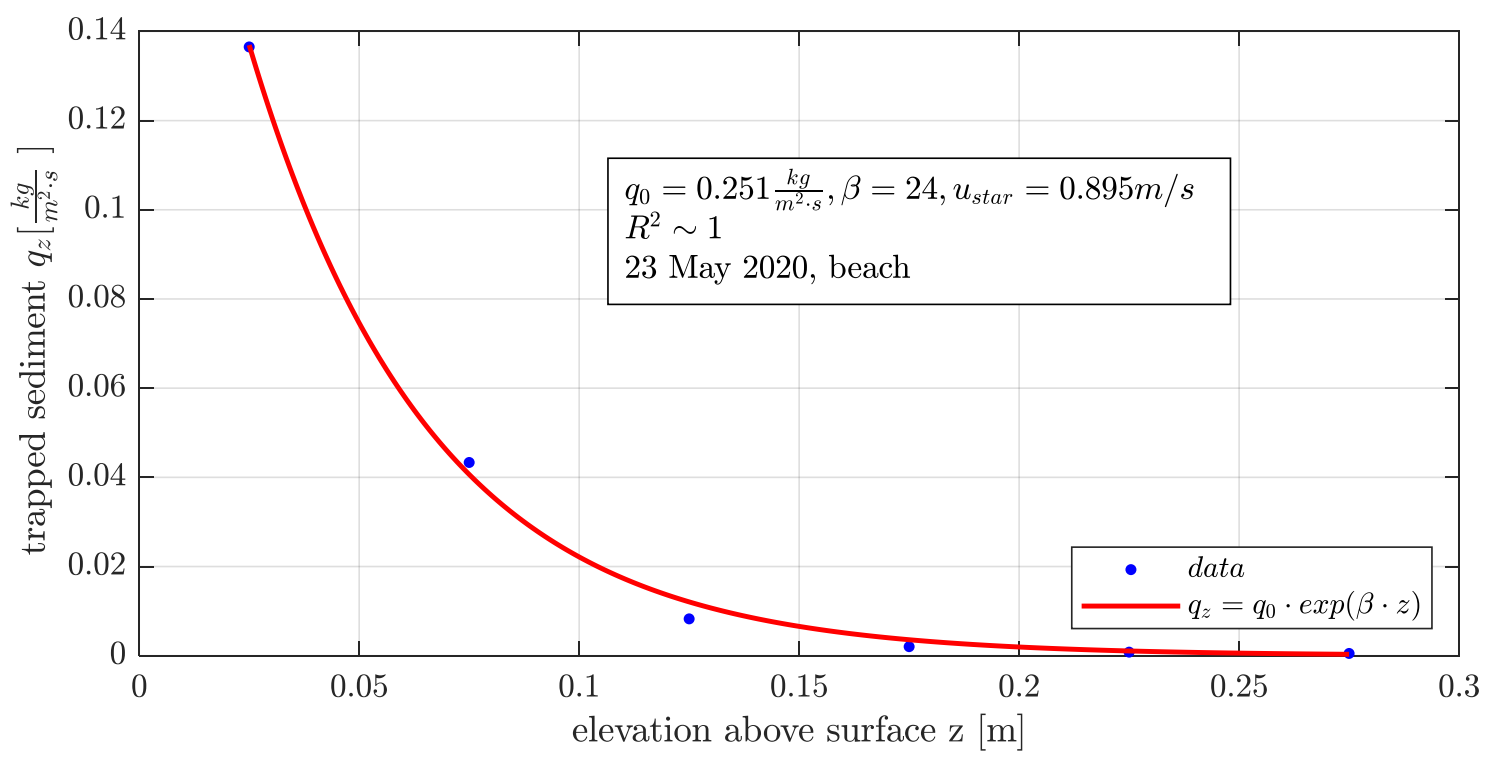

Figure 10. Representative example of the vertical distribution of sediment transport flux on the beach derived from the vertical mesh sand trap for the measurement location of the beach and the best fit exponential decay function.

The sand was caught predominantly in heights of less than $z \leq 0.05 \mathrm{~m}$. When the wind was really strong with $u^{*} \sim 1 \mathrm{~m} / \mathrm{s}$, sand was caught in heights over $z>0.15 \mathrm{~m}$. This is in accordance with the literature reporting that most of the sediment transport in coastal areas occurs in a thin layer $z<0.05 \mathrm{~m}$ above the surface [22].

In Tables 2 and 3, the results for the trapped sediment from the vertical mesh sand traps with the total mass flux $Q_{s}[\mathrm{~kg} / \mathrm{m} / \mathrm{h}]$ over the measuring duration $t[\mathrm{~min}]$, with the decay rate $\beta[1 / \mathrm{m}]$ and the extrapolated saltating sediment mass transport at the surface $q_{0}\left[\mathrm{~kg} / \mathrm{m}^{2} / \mathrm{h}\right]$, and the correlation coefficients $R^{2}[-]$ of the regression analysis are shown. The corresponding shear velocity $u^{*}[\mathrm{~m} / \mathrm{s}]$, the moisture content $M[\mathrm{Vol} \%]$, and the aerodynamic roughness length $z_{0}[\mathrm{~mm}]$ from other analyses are also shown. The transport fluxes varied between $Q_{s}=0.65-57.03 \mathrm{~kg} / \mathrm{m} / \mathrm{h}$ with shear velocities up to a maximum of $u^{*}=1.01 \mathrm{~m} / \mathrm{s}$. The measuring duration varied between $t=19-105 \mathrm{~min}$.

Table 2. Results of the total mass flux over the measuring duration, decay rate, extrapolated saltating sediment mass transport at the surface, correlation coefficients of the regression analysis of the vertical wind profile (rounded values), shear velocity, moisture content, and aerodynamic roughness length.

\begin{tabular}{|c|c|c|c|c|c|c|c|c|c|}
\hline Location & No. & $\begin{array}{c}Q_{s} \\
{[\mathrm{~kg} / \mathrm{m} / \mathrm{h}]}\end{array}$ & $\begin{array}{c}t \\
{[\mathrm{~min}]}\end{array}$ & $\begin{array}{c}\beta \\
\beta 1 / \mathrm{m}]\end{array}$ & $\begin{array}{c}q_{0} \\
{\left[\mathrm{~kg} / \mathrm{m}^{2} / \mathrm{h}\right]}\end{array}$ & $\begin{array}{l}R^{2} \\
{[-]}\end{array}$ & $\begin{array}{c}u^{*} \\
{[\mathrm{~m} / \mathrm{s}]}\end{array}$ & $\begin{array}{c}M \\
{[\mathrm{Vol} \%]}\end{array}$ & $\begin{array}{c}z_{0} \\
{[\mathrm{~mm}]}\end{array}$ \\
\hline \multirow{8}{*}{ Beach } & 1 & 27.83 & 49 & 35 & 966.70 & 1.00 & 1.05 & 8.67 & 0.64 \\
\hline & 2 & 50.72 & 53 & 17 & 839.68 & 0.97 & 0.99 & 8.57 & 0.52 \\
\hline & 3 & 47.62 & 83 & 13 & 610.52 & 0.88 & 0.96 & 10.38 & 0.43 \\
\hline & 4 & 37.29 & 46 & 24 & 904.85 & 1.00 & 0.89 & 7.47 & 0.33 \\
\hline & 5 & 27.38 & 43 & 39 & 1075.91 & 1.00 & 0.88 & 8.54 & 0.39 \\
\hline & 6 & 57.03 & 58 & 29 & 1676.80 & 1.00 & 0.97 & 8.28 & 0.47 \\
\hline & 7 & 43.44 & 27 & 39 & 1696.28 & 1.00 & 0.90 & 7.08 & 0.34 \\
\hline & 8 & 22.77 & 19 & 46 & 1048.21 & 1.00 & 0.85 & 7.82 & 0.28 \\
\hline \multirow{3}{*}{$\begin{array}{l}\text { Dune } \\
\text { toe }\end{array}$} & 9 & 2.70 & 105 & 48 & 122.33 & 0.91 & 0.42 & 1.10 & 0.03 \\
\hline & 10 & 1.34 & 105 & 63 & 83.69 & 0.88 & 0.42 & 1.53 & 0.03 \\
\hline & 11 & 0.65 & 105 & 24 & 13.76 & 0.91 & 0.42 & 1.80 & 0.03 \\
\hline
\end{tabular}


Table 3. Results of the total mass flux over the measuring duration, decay rate, extrapolated saltating sediment mass transport at the surface, correlation coefficients of the regression analysis of the vertical wind profile (rounded values), shear velocity, moisture content, and aerodynamic roughness length.

\begin{tabular}{|c|c|c|c|c|c|c|c|c|c|}
\hline Location & No. & $\underset{[\mathrm{kg} / \mathrm{m} / \mathrm{h}]}{Q s}$ & $\begin{array}{r}t \\
{[\mathrm{~min}]}\end{array}$ & $\begin{array}{c}\beta \\
{[1 / \mathrm{m}]}\end{array}$ & $\begin{array}{c}q_{0} \\
{\left[\mathrm{~kg} / \mathrm{m}^{2} / \mathrm{h}\right]}\end{array}$ & $\begin{array}{c}R^{2} \\
{[-]}\end{array}$ & $\begin{array}{r}u^{*} \\
{[\mathrm{~m} / \mathrm{s}]}\end{array}$ & $\begin{array}{c}M \\
{[\mathrm{Vol} \%]}\end{array}$ & $\begin{array}{r}z_{0} \\
{[\mathrm{~mm}]}\end{array}$ \\
\hline $\begin{array}{l}\text { Dune } \\
\text { crest }\end{array}$ & \multicolumn{9}{|c|}{$\mathrm{n} / \mathrm{a}$, no sediment transport took place } \\
\hline \multirow{6}{*}{$\begin{array}{l}\text { Sand } \\
\text { trapping } \\
\text { fence } 1\end{array}$} & 12 & 11.92 & 69 & 39 & 462.06 & 1.00 & 0.90 & 8.73 & 0.36 \\
\hline & 13 & 6.42 & 65 & 42 & 268.87 & 1.00 & 0.62 & 8.67 & 0.14 \\
\hline & 14 & 39.62 & 20 & 36 & 1416.88 & 1.00 & 0.97 & 5.67 & 0.32 \\
\hline & 15 & 6.47 & 80 & 37 & 199.05 & 1.00 & 0.97 * & 5.67 & 0.32 * \\
\hline & 16 & 5.24 & 80 & 34 & 157.17 & 1.00 & 1.01 & 5.22 & 0.78 \\
\hline & 17 & 21.74 & 80 & 31 & 662.45 & 1.00 & 1.01 * & 3.43 & 0.78 * \\
\hline Sand & 18 & 0.89 & 60 & 33 & 25.77 & 0.93 & $* *$ & 10.30 & $* *$ \\
\hline trapping & 19 & 2.45 & 60 & 36 & 79.53 & 1.00 & $* *$ & 4.77 & $* *$ \\
\hline fence 2 & 20 & 4.80 & 60 & 60 & 314.97 & 1.00 & $1.01 * *$ & 3.65 & $0.78^{* *}$ \\
\hline
\end{tabular}

Sand too little sediment transport to conduct regression analysis, no vertical wind profile according to trapping too little sediment transport to conduct regression analysis, no
fence 3

${ }^{*}$ no wind data available, $u^{*}$ and $z_{0}$ assumed from data of the closest time interval; ${ }^{* *}$ no wind data available between the sand trapping fence.

The regression analysis of the transport fluxes showed correlation coefficients around $R^{2}=0.88-1.00$. The regression parameters varied with $\beta=29-63 / \mathrm{m}$ and $q_{0}=25.77-1696.28 \mathrm{~kg} / \mathrm{m}^{2} / \mathrm{h}$.

The decay rate generally increases for a constant saltating sediment mass transport at the surface with higher wind velocity or less moisture content, indicating that more sand is transported at higher elevations above the surface [56]. Considerable variation was present when comparing the decay rate and saltating sediment mass transport at the surface for different measurement locations, where the prevailing boundary conditions, like the moisture content and shear velocities, varied. Close to the dune toe, the wind regime was of medium intensity, and the sand was relatively dry, resulting in lower saltation heights, compared to the beach and sand trapping fence, when it was relatively wet; however, high wind velocities occurred. The presence of slightly wet sand increased the threshold of motion for sand, resulting in a lower total sediment flux.

Aeolian sediment transport is highly variable in both space and time. During one event, the trapped sand in two vertical mesh sand traps standing next to each other can vary a lot. This happens, if wind forces and sand transport occur in the form of streamers resulting in spatial-temporally changing threshold shear velocity $[22,26,35,78]$.

At the measurement location of the sand trapping fence, position 3, there was too little sediment caught in the vertical mesh sand trap over the defined time interval. Thus, the vertical sediment flux profile cannot be described with the approach according to Equation (3).

The literature gives a wide range of fitting coefficients and different methods for trapping sand above the surface $[22,68,78,79]$. The studies at the Belgian coast at Mariakerke and Koksijde are described in the following to compare the results of this work with other authors. Strypsteen (2019) [22] measured the trapped sand with Modified Wilson And Cool Samplers (MWAC) on a dry beach, where the bottles were placed at the heights of $z=6.5,13.5,21$, and $28.5 \mathrm{~cm}$ above the surface. The results were analyzed with the potential decay function as an average value out of 12 measurement locations on the beach. With an average shear velocity between $u^{*}=0.29-0.54 \mathrm{~m} / \mathrm{s}$ and transport fluxes between $Q_{s}=7.2-121.8 \mathrm{~kg} / \mathrm{m} / \mathrm{h}$, the decay rate varied between $\beta=14.06-28.57 / \mathrm{m}$. The measuring time varied between minutes up to days depending on the intensity of the sediment transport [87].

Campos (2018) [56] measured the sediment transport fluxes with vertical mesh sand traps on the Belgian coast at Koksijde. With an average shear velocity between $u^{*}=0.40-0.53 \mathrm{~m} / \mathrm{s}$ and transport fluxes between $Q_{s}=38.4-88 \mathrm{~kg} / \mathrm{m} / \mathrm{h}$, the decay rate varied between $\beta=18.13-23.72 / \mathrm{m}$. In the study, 
each run was performed nine times with measurement durations between $t=16 \min$ up to $t=38 \mathrm{~min}$. Little to no moisture was present [56].

These two selected field campaigns measured significantly higher total mass flux but lower shear velocities and decay rates. This could be explained by the presence of slightly wet sand on the study site Langeoog, increasing the threshold of motion for the sand, resulting in a lower total sediment flux (see also Section 2) for higher shear velocities. Further reasons for these deviations may be that Campos (2018) [56] used shorter time intervals for trapping the sand in the vertical mesh traps. The trap efficiency of the measurement tool MWAC, stated as the ratio of total particle mass passing through the air per defined area to the actual value, varies between $42 \%-120 \%[59,88,89]$. For the vertical mesh sand traps, there was good efficiency reported; however, the efficiency decreased for longer time periods $[55,56]$. The MWAC sand trap began measuring at $z \geq 6.5 \mathrm{~cm}$ above the surface, whereas the vertical sand trap began measuring right above the sand surface.

\subsection{Observed Aeolian Sediment Transport Rates at the Measurement Location of the Beach}

In Figure 11, the theoretical comparison between the field data of Langeoog beach, dune toe, sand trapping fence (position 1), and five chosen transport models derived by Bagnold (1937) [80], Kawamura (1951) [82], Bagnold (1954) [23], Kok et al. (2012) [31], and van Rijn (2019) [35] (see also Table 1) are shown. The Bagnold (1954) [23] model results in the smallest transport rates compared to the other prediction models, especially for smaller shear velocities. The orange dots show the results of the location beach, the blue dots of the location dune toe, and the brown dots of the location sand trapping fence (location 1).

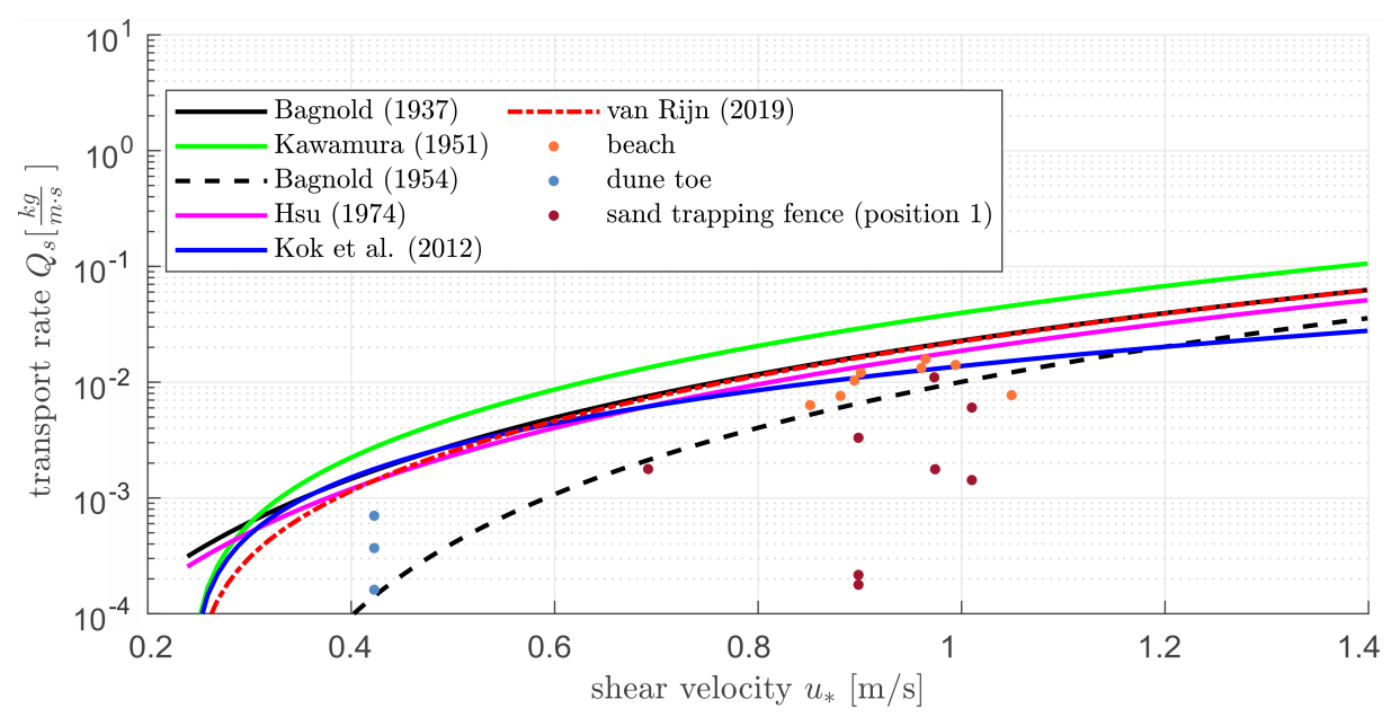

Figure 11. Comparison between the measured sediment transport rates on Langeoog and the predicted sediment transport rates for five different transport models.

The measured data from Langeoog beach can be described well with the predicted transport models if the moisture content as a reduction factor is considered. For the location dune toe and sand trapping fences (position 1) the results scattered more but still showed good results. We could not clearly evaluate which equation fit the results best as only high wind velocities with shear velocities around $u^{*}=0.70-1.05 \mathrm{~m} / \mathrm{s}$ were recorded, except for $u^{*}=0.42 \mathrm{~m} / \mathrm{s}$, where the results scattered a lot. For further analysis, smaller shear velocities are required to indicate the best fit regression line.

An application of the transport models from Table 1 is only useful for the entrance boundary condition (upwind the sand trapping fence, position 1). Between the sand trapping fences, the transport models cannot be used as the sediment supply from above was too small and a logarithmic wind profile no longer existed (see Section 4.1). 


\subsection{Downwind Evolution of Saltiphone Data for the Measurement Location Beach}

In Figure 12, an example of the wind and saltiphone data on the beach on 23 May 2020 for the time interval 12:35 pm to 13:10 pm is shown. This is a representative example out of four repeating measurements on the beach. The calculated shear velocities from the wind profiles and the mean wind direction are shown as an average value over $10 \mathrm{~s}$. The critical shear velocity is also given, see Figure 12a. Additionally, the 95\% quantiles of the saltation impacts over 10-s time intervals are shown. In Figure 12a, the black line represents the calculated shear velocity, the dotted red line indicates the critical shear velocity $\left(u^{* t}=0.24 \mathrm{~m} / \mathrm{s}\right.$, see Section 3.2.1), whereas the light orange line shows the mean wind direction. Figure $12 \mathrm{~b}$ shows the saltiphone data for position 1 and (c) for position 2, with (d) for position 3 in the downwind direction. The blue bars represent the counted sand grains of the lower saltiphones, and the orange bars are for the upper saltiphones. In terms of the wind conditions, the experiments at the beach were intense with an average wind velocity of $u_{2}=19.2 \mathrm{~m} / \mathrm{s}$ $\left(u^{*}=0.88 \mathrm{~m} / \mathrm{s}\right)$, resulting in saltation impacts up to $s=750$ impacts $/ 10 \mathrm{~s}$. The wind came from the west (wind direction $d r=274^{\circ}$ ) with slight wind velocity fluctuations.

(a)

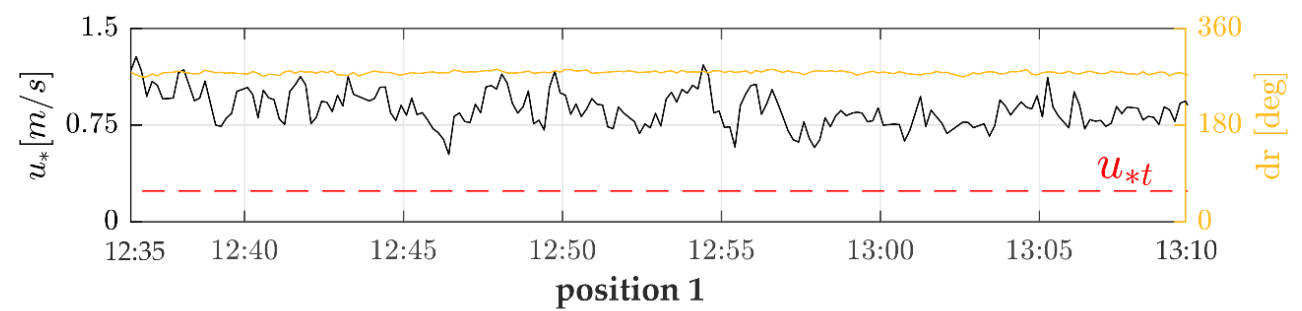

(b)

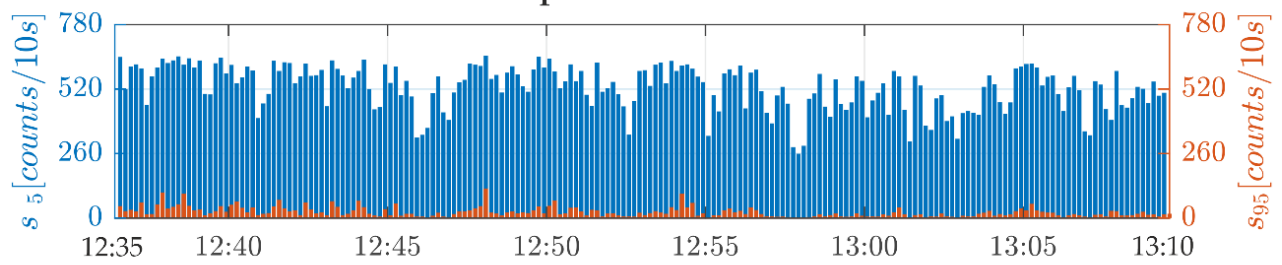

(c)

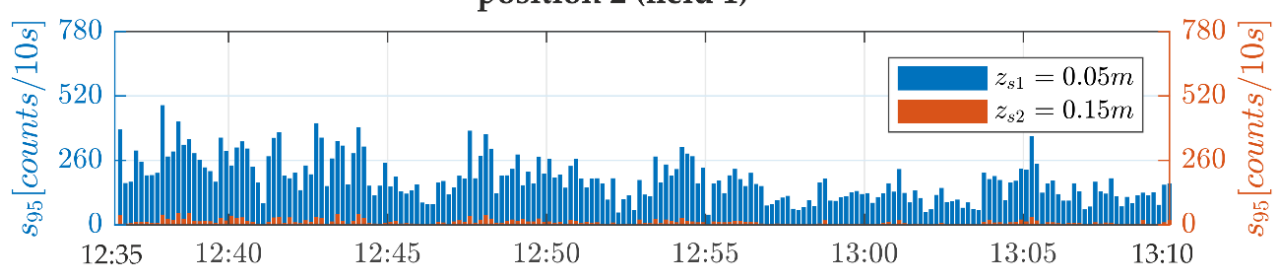

(d)

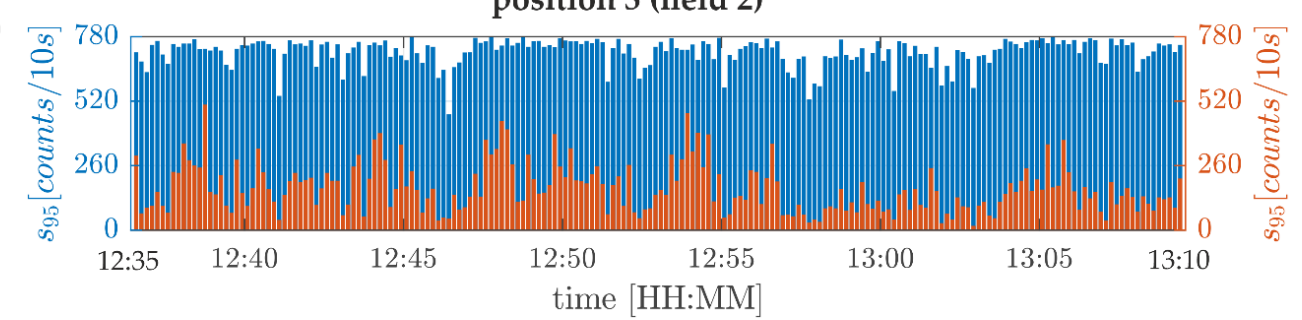

Figure 12. Time series of the (a) shear velocity, critical shear velocity, mean wind direction, and (b-d) $95 \%$ quantiles of saltation impacts over 10-s time intervals for the measurement location of the beach conducted on 23 May 2020.

The shear velocity was always above the critical shear velocity during the whole experiment, showing continuous sediment transport for all three positions. In general, as the number of counted sediment grains on the lower saltiphone increased, so did the number of counted sediment grains on the upper saltiphone. This suggests that the height of the saltating layer increased. At position 2 (20 m downwind), lower impacts were measured compared to position 1, followed by an increase of the 
saltation impacts at position 3 ( $40 \mathrm{~m}$ downwind). The smaller number of impacts at the second location can likely be attributed to a higher moisture content or more shells, protecting the beach against the erosion of sand grains, resulting in higher critical shear velocities [35,90,91].

We assumed that, between location 1 and location 2, there was a sediment sink due to the high moisture contents, whereas, between position 2 and position 3, there was a sediment source with lower moisture contents. During the whole day, the moisture content was relatively high with values around $M=3.3-14.5 \mathrm{Vol} \%$, showing almost saturated values. However, the moisture content was very variable in time and space. The higher moisture content resulted in higher critical shear velocities compared to the dune toe, where the sand was relatively dry.

\subsection{Downwind Evolution of Saltiphone Data for the Measurement Location of the Dune Toe}

In Figure 13, a representative example of the wind and saltiphone data close to the dune toe on 19 May 2020 for the time interval 12:15 pm to 13:05 pm is shown. This is an example out of three repeated measurements of the dune toe.

(a)

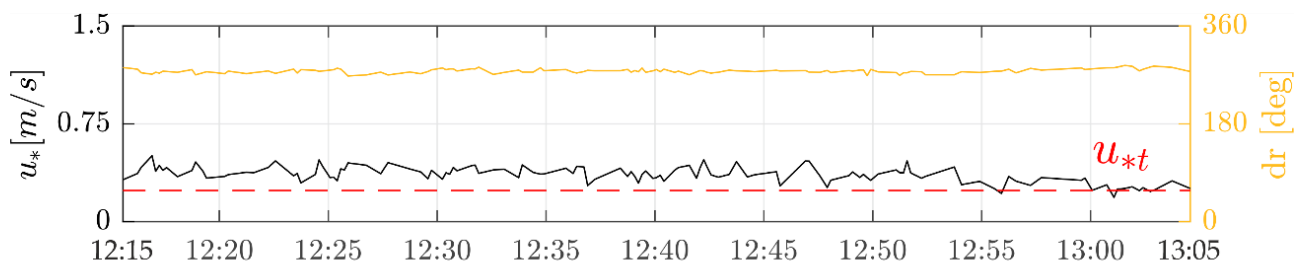

(b)

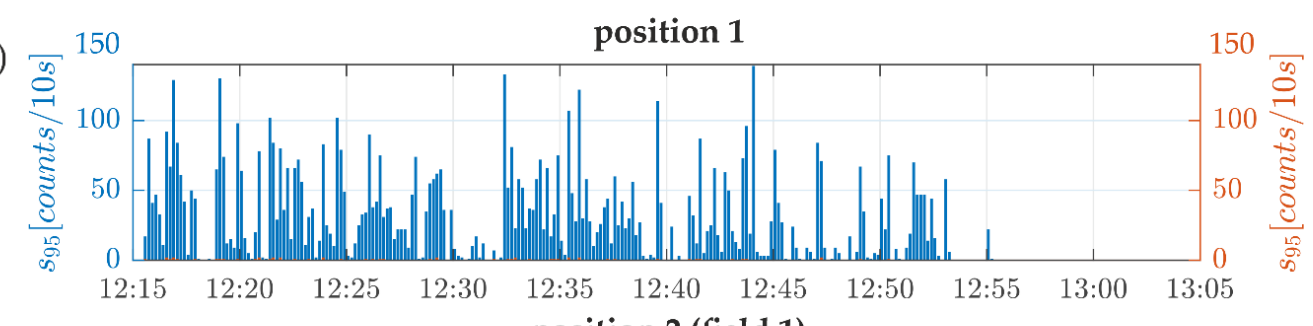

(c)

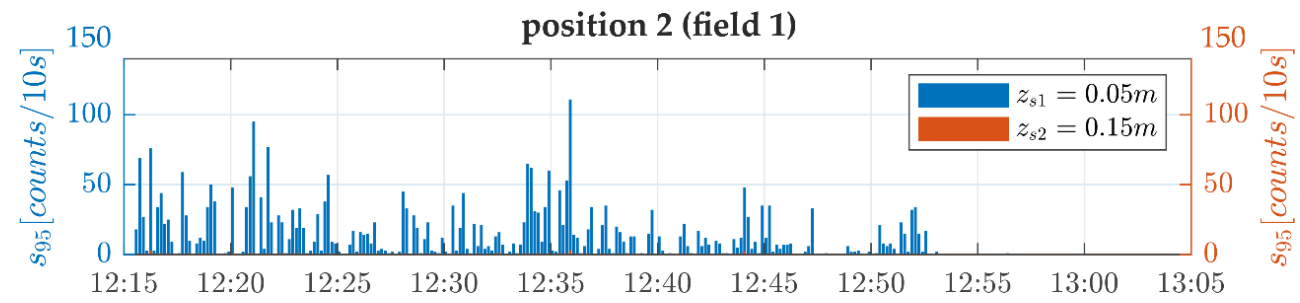

(d)

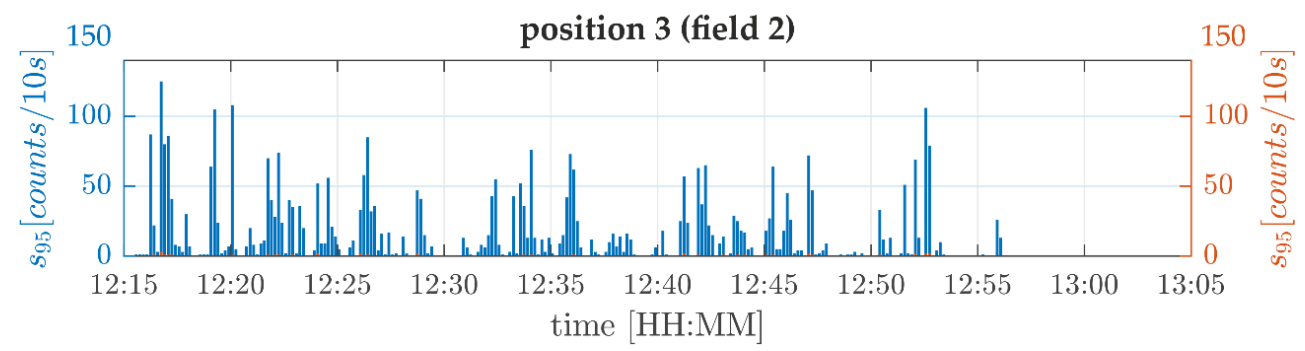

Figure 13. Time series of the (a) shear velocity, critical shear velocity, mean wind direction, and (b-d) $95 \%$ quantiles of saltation impacts over 10-s time intervals for the measurement location of the dune toe conducted on 19 May 2020.

The average wind velocity was $u_{2}=11.6 \mathrm{~m} / \mathrm{s}$, and the average shear velocity was $u^{*}=0.36 \mathrm{~m} / \mathrm{s}$. The wind was relatively steady coming from west $\left(d r=277^{\circ}\right)$, parallel to the dune. During the time interval shown in Figure 13, the shear velocity was mostly slightly above the critical shear velocity, whereby, around 12:56 pm and 13:02 pm, the critical shear velocity was undercut, and no sediment 
transport was further measured. The results, therefore, indicate that the calculated critical shear velocity was a good approximation of the threshold for the initiation of sediment transport.

The lower saltiphones recorded more impacts than the upper saltiphones. As only sporadic saltation impacts were measured by the upper saltiphones, they are hard to distinguish in Figure 13; see, for example, Figure $13 \mathrm{~b}$ around 12:17 pm. The number of impacts measured by the upper saltiphones increased due to a wind peak. This shows that most of the sediment transport occurred below $z \leq 0.15 \mathrm{~m}$. This also agrees with the results of the vertical mesh sand traps close to the dune toe, where at heights of $z \geq 0.15 \mathrm{~m}$ above the surface little sediment were caught (see also Section 4.2).

Time intervals with increased saltation impacts corresponded temporally for all measuring positions downwind. Most grain impacts were recorded at position 1, followed by position $2(20 \mathrm{~m}$ downwind) and position $3(40 \mathrm{~m})$ approximately in the same order of magnitude. The peaks in the wind velocity correspond with the peaks in the counted particles by the saltiphones.

Little spatial variations in sediment transport gradients are found downwind and reflect the spatially varying availability of sand related to the surface roughness and moisture. The moisture content of the sand close to the dune was relatively low with average values around $M \sim 1.1-1.8 \mathrm{Vol} \%$ and, therefore, played a minor role for supply limiting factors. However, due to the medium intense wind velocities, the bed ripples moved downwind, causing a high spatial variability of the aerodynamic roughness length (see also Figure 4). Generally, these ripples occur with wind velocities of $u=5-10 \mathrm{~m} / \mathrm{s}$, and, with higher wind velocities, these ripples are gradually smoothed out [67].

\subsection{Downwind Evolution of Saltiphone Data Influenced by Sand Trapping Fences}

In Figure 14, a representative example of the time series on 24 May 2020 from 09:45 am to 10:08 am for the measurement location sand trapping fence is shown. This is a representative example out of thirteen repeating measurements. Position 1 is in front of the sand trapping fence and is treated as a boundary condition for incoming sediment that accumulates at the brushwood lines of the sand trapping fence. Position 2 (field 1) and position 3 (field 2) are in between the sand trapping fences at $10 \mathrm{~m}$ and $20 \mathrm{~m}$, respectively, downwind (see Figure 6). All three locations belong to the sand trapping configuration 1 , see Figure $2 \mathrm{a}$. The average wind velocity at $2 \mathrm{~m}$ of height was $u_{2}=20.8 \mathrm{~m} / \mathrm{s}$ with a few fluctuations. The shear velocity was $u^{*}=0.94 \mathrm{~m} / \mathrm{s}$ and always above the critical shear velocity. The wind direction was relatively steady coming from the west $\left(d r=262^{\circ}\right)$, which implies parallel wind to the dune. 
(a)

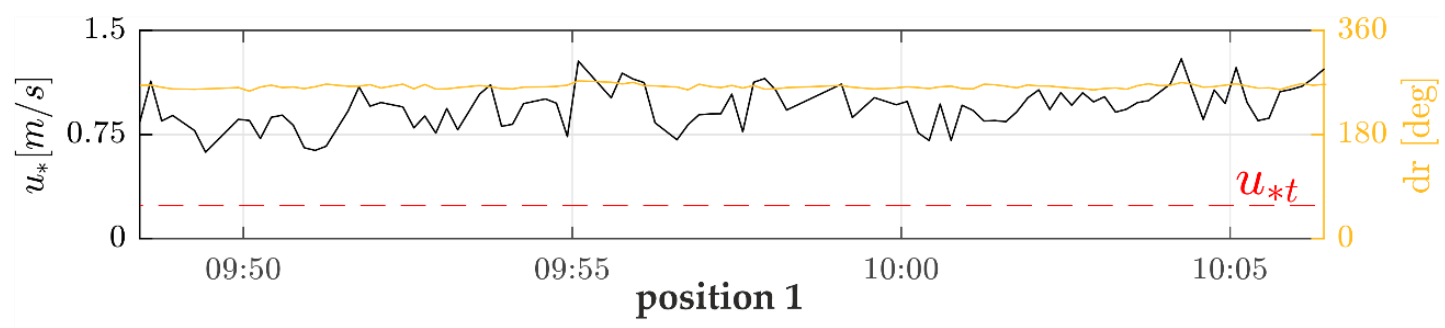

(b)

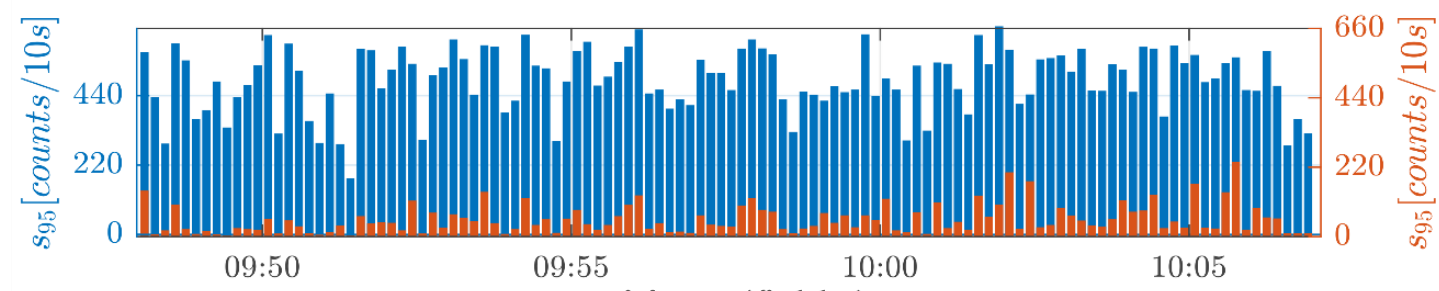

(c)

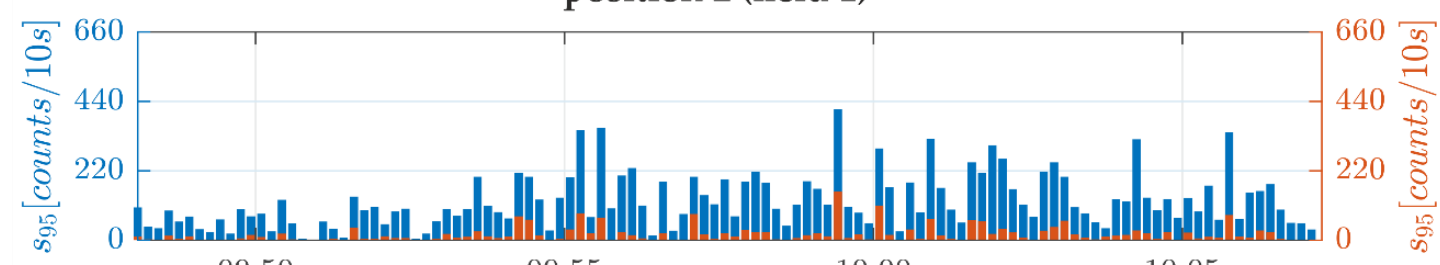

09:50

09:55

10:00

10:05

position 3 (field 2)

(d)

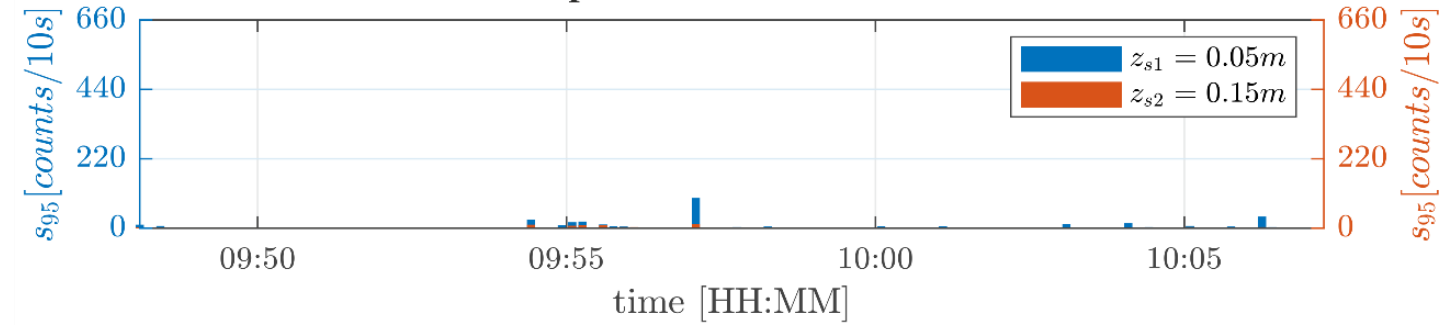

Figure 14. Time series of the (a) shear velocity, critical shear velocity, mean wind direction, and (b-d) $95 \%$ quantiles of saltation impacts over 10-s time intervals for the measurement location of the sand trapping fence conducted on 24 May 2020.

The number of counted particles decreased in the downwind direction behind the first line of brushwood of the sand trapping fence. In the first field of the sand trapping fence, less sediment was transported than in front of the sand trapping fence. In the second field, even less sediment was transported. With the measured wind conditions and the given time interval, the sand transport between the sand trapping fence could only be measured up to the second sand trap field. In field 2, the counted saltiphones were almost not measurable or zero.

In Figure 15, 95\% quantiles of the counted sand grains $s_{95}$ [counts/10 s] at position $i$ relative to the boundary condition $s_{95}$,position 1 [counts/10 s] in percentage over the distance downwind $y[\mathrm{~m}]$ through the sand trapping fence for different shear velocities are shown. The $95 \%$-quantiles of the saltation impacts were averaged over a 60-min time interval with approximately the same shear velocity. Position 1 (upwind of the sand trapping fence) was taken as the boundary condition with an input of $100 \%$ saltation impacts. In field 1 and field 2, the saltiphone data are shown relative to the boundary condition (position 1). To illustrate the decrease in the saltation impacts before and between the sand trapping fence in a simplified way, the saltation impacts are shown constant over the distance downwind $\mathrm{y}_{1}=0-10 \mathrm{~m}, \mathrm{y}_{2}=10-20 \mathrm{~m}$, and $\mathrm{y}_{3}=20-30 \mathrm{~m}$-although in reality, this is not the case. 
(a) lower saltiphone

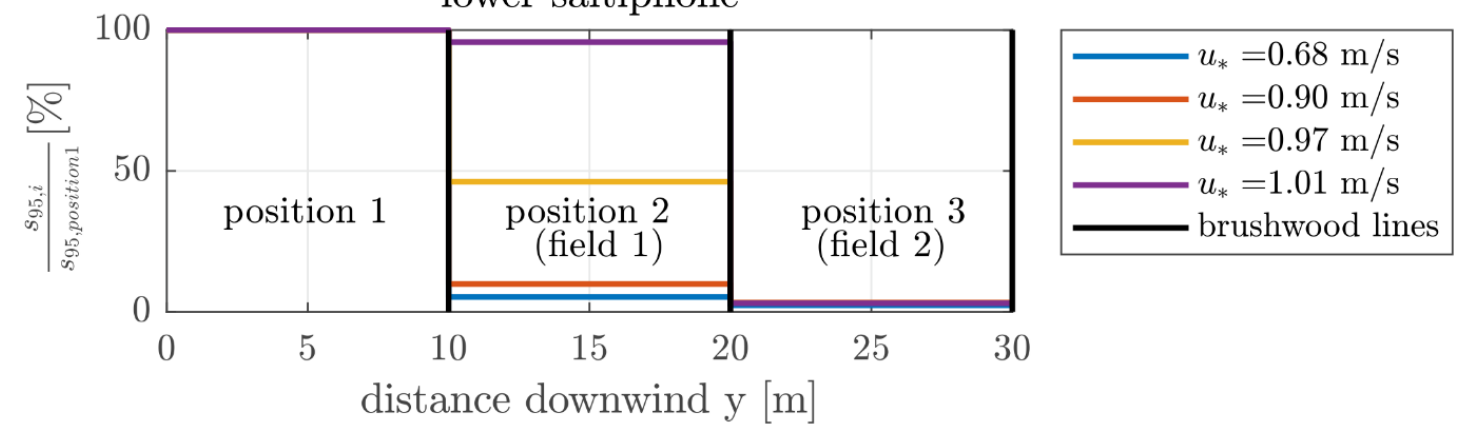

(b)

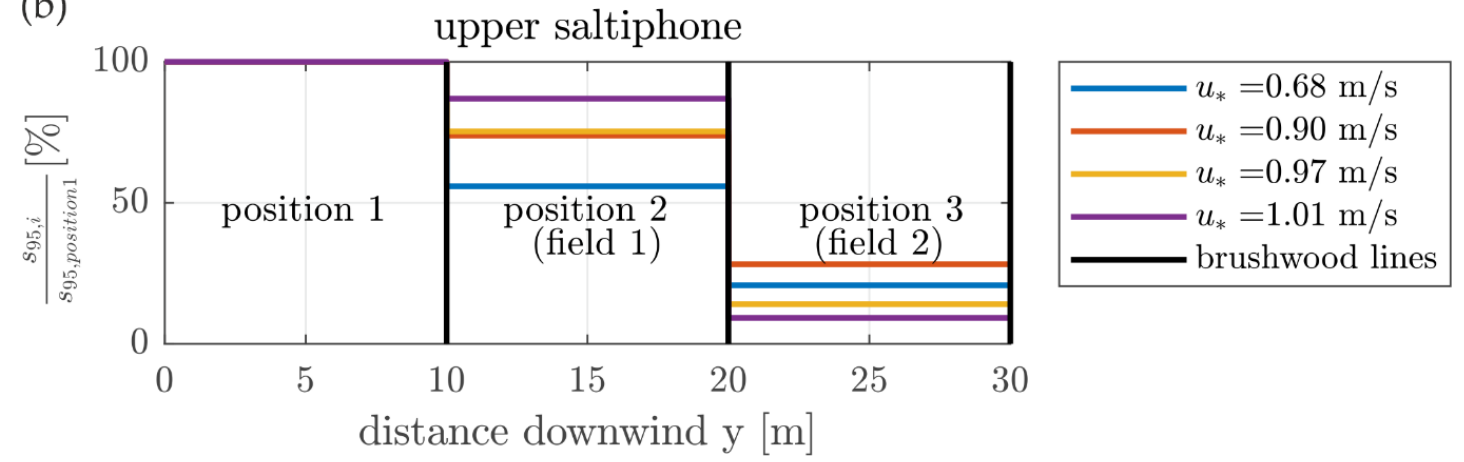

Figure 15. Comparison of the downwind evolution of the saltiphone data before and behind the sand trapping fence for different shear velocities for (a) the lower saltiphone and (b) the upper saltiphone.

For all shear velocities between $u^{*}=0.68-1.01 \mathrm{~m} / \mathrm{s}$, the counted saltation impacts were significantly reduced between the sand trapping fences, indicating the deposition of sand in the distance downwind. In field 1 (position 2), the sediment transport for the lower saltiphone was reduced between 5-95\% compared to position 1, and, in field 2 (position 3), the sediment transport was reduced between $96-98 \%$ compared to position 1 . For the upper saltiphone, the sediment transport in field 1 (position 2) was reduced between 13-44\% compared to position 1, and, in field 2 (position 3 ), the sediment transport was reduced between $72-91 \%$ compared to position 1 . At high shear velocities of up to $u^{*}=1.01 \mathrm{~m} / \mathrm{s}$, the sand transport in field 1 was only slightly reduced for both saltiphone heights. For the upper saltiphone, the saltation impact was less reduced compared to the lower saltiphone. Due to the installation of the bundled brushwood, the sand trapping fence was relatively dense directly above the bed surface. This indicates that more sediment grains hit the brushwood and were deposited close to the bed surface.

The investigation at the sand trapping fence were conducted directly after the installation of the sand trapping fence, and, therefore, the fields caught relatively little sand. Sediment was caught predominantly by the first two brushwood lines, where sediment transport could also be measured. This implies that the first two brushwood lines of this type of sand trapping fence configuration (see also Figure 2), with the westerly longshore wind and the actual amount of trapped sand in between the sand trapping fence, were the most effective brushwood lines to trap sand. However, on Langeoog, many of the elderly installed sand trapping fences are already completely filled with sand, showing that not only the first two brushwood lines exposed to longshore wind but also the brushwood lines that are not in an exposed wind position trap sand effectively. This can be explained by the fact that strong winds from the west over north to south can also transport sediment to the sand trapping fence, where it can accumulate at the brushwood lines orthogonal and parallel to the coastal dune. In addition, with a larger amount of trapped sediment between the individual brushwood lines and longshore wind, other fields (not directly exposed to the longshore wind) can be filled with sediment as well. 


\section{Conclusions}

This work presents the results of field experiments conducted on the coast of the East Frisian island Langeoog, analyzing wind and sediment transport data the beach, coastal dune, and sand trapping fence. The following conclusions can be drawn from the results presented in this work:

(1) The logarithmic wind profiles for the beach, the area close to the dune toe, the dune crest of the foredunes, and upwind of the sand trapping fence (position 1) can be well described by the law of the wall. In between the sand trapping fence, no stationary logarithmic velocity profile was present. Here, the wind directions and the wind velocities varied considerably over the distance from the bottom for any given point in time. We assumed that turbulent fluctuations took place, and therefore the effects of short-time variations in surface roughness associated with large eddies cannot be displayed appropriately by a one-dimensional wind profile. The values for the aerodynamic roughness length close to the dune toe, on the beach, and in front of the sand trapping fence can be described as a function of the shear velocity. At the dune crest, where vegetation was present, the values were $\sim 100$ times higher. With increasing aerodynamic roughness length, the shear velocity also increased.

(2) The vertical sediment flux profile of aeolian sand transport for the measurement locations of the beach, dune toe, and sand trapping fence (position 1 and 2) can be described well with an empirical exponential decay function. The regression parameters exponential decay rate and the extrapolated saltation flux at the surface were subject to considerable variation for different measurement locations. Close to the dune toe, the wind regime was of medium intensity, and the sand was relatively dry. On the beach and between the sand trapping fence, high wind velocities occurred, and the sand was relatively wet, resulting in higher critical shear velocities and lower total sediment fluxes.

(3) The sediment caught in the vertical mesh sand traps divided through the inlet area and the measurement duration could well describe the sediment transport rates on the coastal area. The results are described well by the transport models derived by Bagnold (1937) [80], Kawamura (1951) [82], Bagnold (1954) [23], Kok et al. (2012) [31], and van Rijn (2019) [35], considering the moisture content as a further reduction factor. Between the sand trapping fences, these transport models cannot be applied as no logarithmic wind profile existed and the upwind sediment supply was reduced after each brushwood line, thereby, leading to increased deviation from the saturated conditions.

(4) The saltiphones are a good measurement tool to determine the moment sediment transport is initiated and, thus, for determining the value of the critical shear velocity. Small spatial variations in the sediment transport gradients were found downwind close to the dune toe. They reflected the spatially varying availability of erodible sand, which is related to the surface roughness and moisture. However, due to the medium intense wind velocities, the bed ripples were moving downwind, causing a high spatial variability of aerodynamic roughness length. At the measurement location of the beach (position 2, $20 \mathrm{~m}$ downwind), a smaller number of impacts were measured compared to position 1 , followed by an increase of the saltation impacts at position 3 (40 m downwind). We assumed that, between location 1 and location 2, a sediment sink was present due to the high moisture contents, whereas, between position 2 and 3, we assumed a sediment source was present due to the lower moisture contents. During the whole field campaign, the moisture content was high resulting in higher critical shear velocities.

(5) Sediment transport was significantly reduced by the sand trapping fence. The sand transport was highest upwind of the sand trapping fence. Downwind, in field 1 and field 2, the sediment transport for the lower and upper saltiphones was reduced. In field 2, the sediment transport was almost not measurable or zero.

This study provided the first insights into aeolian sediment transport at different locations on the coastal dune and the influence of sand trapping fences on aeolian sediment transport. We strongly 
recommend to extend the knowledge of the influences of sand trapping fences on aeolian sediment transport in standardized wind tunnel experiments to gain more quantitative data. To evaluate the influence of sand trapping fences on dune development for longer timescales, aerial drone investigations of the coastal dune should be conducted on the study site Langeoog. For this purpose, an analysis of a series of digital elevation models at the coastal dune and at the sand trapping fence will be performed to investigate the dune volume changes around the fence depending on each sand trapping configuration. The aim of the future investigation is to evaluate the efficiency of each sand trapping configuration under different prevailing wind conditions.

Author Contributions: Conceptualization, C.E. and H.S.; methodology, C.E.; formal analysis, C.E.; investigation: C.E., data processing, C.E., resources, H.S.; original draft preparation, C.E.; review and editing, H.S.; visualization, C.E.; supervision, H.S.; project administration, H.S.; and funding acquisition, C.E., H.S., and others. All authors have read and agreed to the published version of the manuscript.

Funding: This research was funded by the German Federal Ministry of Education and Research (BMBF) within the project ProDune (grant number 03KIS125) that was initiated in the framework of the German Coastal Engineering Research Council (KFKI).

Acknowledgments: The authors thank the project partner Lower Saxony Water Management, Coastal Protection and Nature Conservation Agency for their help in attaining permission to conduct the field experiments and for sharing their expertise in the project support group. The authors thank the administration of the National Park Wadden Sea of Lower Saxony for the permission to conduct the field experiments on the East Frisian Islands. We, furthermore, thank the technical staff and student assistants of the IWW for their help in conducting the field experiments.

Conflicts of Interest: The authors declare no conflict of interest. The funders had no role in the design of the study; in the collection, analyses, or interpretation of data; in the writing of the manuscript, or in the decision to publish the result.

\section{References}

1. Peters, K.; Pohl, M. Kuratorium für Forschung im Küsteningenieurwesen (German Coastal Engineering Research Council). Die Küste (The Coast), Issue 88, EAK 2002, Empfehlungen für die Ausführung von Küstenschutzwerken durch den Ausschuss für Küstenschutzwerke der Deutschen Gesellschaft für Geotechnike.V. und der Hafenbautechnischen Gesellschaft e.V. (Recommendations for Coastal Protection Structures. Working group 'Coastal Protection Structures' as a Joint Commitee of the German Geotechnical Society and the German Port Technology Association); Westholsteinische Verlagsanstalt Boyens \& Co.: Heide, Germany, 2020; ISBN 978-3-939239-54-0.

2. Niedersächsischer Landesbetrieb für Wasserwirtschaft, Küsten- und Naturschutz (Lower Saxony Water Management, Coastal Protection and Nature Conservation Agency). Generalplan Küstenschutz Niedersachsen: Ostfriesische Inseln, Küstenschutz Band 2; Niedersächsischer Landesbetrieb für Wasserwirtschaft, Küsten- und Naturschutz (Lower Saxony Water Management, Coastal Protection and Nature Conservation Agency): Lower Saxony, Germany, 2010.

3. Short, A.D.; Hesp, P.A. Wave, Beach and Dune Interactions in Southeastern Australia. Mar. Geol. 1982, 48, 259-284. [CrossRef]

4. Nordstrom, K.F.; Jackson, N.L.; Korotky, K.H.; Puleo, J.A. Aeolian transport rates across raked and unraked beaches on a developed coast. Earth Surf. Process. Landforms 2011, 36, 779-789. [CrossRef]

5. Ranwell, D.; Boar, R. Coast Dune Management Guide; Institute of terrestrial Ecology: Wallingford, UK, 1986.

6. Hillmann, S.; Blum., H.; Thorenz, F. National Analysis_Germany Lower Saxony; Niedersächsischer Landesbetrieb für Wasserwirtschaft, Küsten- und Naturschutz (Lower Saxony Water Management, Coastal Protection and Nature Conservation Agency): Lower Saxony, Germany, 2019.

7. De Vries, S. Physics of Blown Sand and Coastal Dunes. Ph.D. Thesis, Delft University of Technology, Delft, The Netherlands, 2013.

8. Pye, K.; Saye, S.; Blott, S. Sand Dune Processes and Management for Flood and Coastal Defence: Part 4: Techniques for Sand Dune Management; R\&D Technical Report FD1392/TR 2007; Environment Agency: Bristol, UK, 2007.

9. Scheres, B.; Schüttrumpf, H. Nature-Based Solutions in Coastal Research-A New Challenge for Coastal Engineers? In APAC 2019; Viet, N.T., Xiping, D., Tung, T.T., Eds.; Springer Singapore: Singapore, 2020; pp. 1383-1389. ISBN 978-981-15-0290-3. 
10. Sutton-Grier, A.; Gittman, R.; Arkema, K.; Bennett, R.; Benoit, J.; Blitch, S.; Burks-Copes, K.; Colden, A.; Dausman, A.; DeAngelis, B.; et al. Investing in Natural and Nature-Based Infrastructure: Building Better Along Our Coasts. Sustainability 2018, 10, 523. [CrossRef]

11. Morris, R.L.; Konlechner, T.M.; Ghisalberti, M.; Swearer, S.E. From grey to green: Efficacy of eco-engineering solutions for nature-based coastal defence. Glob. Chang. Biol. 2018, 24, 1827-1842. [CrossRef]

12. Ruz, M.-H.; Anthony, E.J. Sand trapping by brushwood fences on a beach-foredune contact: The primacy of the local sediment budget. Zeitschrift für Geomorphologie Suppl. Issues 2008, 52, 179-194. [CrossRef]

13. Miller, D.; Thetford, M.; Yager, L. Evaluation of Sand Fence and Vegetation for Dune Building Following Overwash by Hurricane Opalon Santa Rosa Island, Florida. J. Coast. Res. 2001, 17, 936-948, West Palm Beach (Florida).

14. Mendelssohn, I.A.; Hester, M.W.; Monteferrante, F.J.; Talbot, F. Experimental Dune Building and Vegetative Stabilization in a Sand-Deficient Barrier Island Setting on the Louisiana Coast, USA. J. Coast. Res. 1991, 7, 137-149, Fort Lauderdale (Florida).

15. Grafals-Soto, R.; Nordstrom, K. Sand fences in the coastal zone: Intended and unintended effects. Environ. Manag. 2009, 44, 420-429. [CrossRef]

16. Li, B.; Sherman, D.J. Aerodynamics and morphodynamics of sand fences: A review. Aeolian Res. 2015, 17, 33-48. [CrossRef]

17. van Thiel de Vries, J.S.M. Dune Erosion during Storm Surges; IOS Press: Amsterdam, The Netherlands, 2009; ISBN 1607500418.

18. Hesp, P. Foredunes and blowouts: Initiation, Geomorphology and Dynamics. Geomorphology 2002, 48, 245-268. [CrossRef]

19. van Rijn, L.C. Coastal erosion and control. Ocean Coast. Manag. 2011, 54, 867-887. [CrossRef]

20. Vellinga, P. Beach and Dune Erosion during Storm Surges. Ph.D. Thesis, Delft University of Technology, Deltares, Delft, The Netherlands, 1986. Publication 372, Delft Hydraulics.

21. D'Alessandro, F.; Tomasicchio, G.R. Wave-dune interaction and beach resilience in large-scale physical model tests. Coast. Eng. 2016, 116, 15-25. [CrossRef]

22. Strypsteen, G. Monitoring and Modelling Aeolian Sand Transport at the Belgian Coast. Ph.D. Thesis, KU Leuven, Faculty of Engineering Technology, Leuven, Belgium, 2019.

23. Bagnold, R.A. The Physics of Blown Sand and Desert Dunes, 2nd ed.; Methuen: London, UK, 1954.

24. Arens, S.M. Rates of aeolian transport on a beach in a temperate humid climate. Geomorphology 1996, 17, 3-18. [CrossRef]

25. Field, J.P.; Pelletier, J.D. Controls on the aerodynamic roughness length and the grain-size dependence of aeolian sediment transport. Earth Surf. Process. Landforms 2018, 43, 2616-2626. [CrossRef]

26. Baas, A.C.W.; Sherman, D.J. Spatiotemporal Variability of Aeolian Sand Transport in a Coastal Dune Environment. J. Coast. Res. 2006, 225, 1198-1205. [CrossRef]

27. Sherman, D.J.; Li, B.; Ellis, J.T.; Farrell, E.J.; Maia, L.P.; Granja, H. Recalibrating aeolian sand transport models. Earth Surf. Process. Landforms 2013, 38, 169-178. [CrossRef]

28. Nickling, W.G.; Davidson-Arnott, R.G.D. Aeolian Sediment Transport on beaches and Coastal Sand dunes. In Proceedings of the Symposium on Coastal Sand Dunes 1990, Guelph, ON, Canada, 12-14 September 1990; pp. 1-35.

29. Nickling, W.G.; McKenna Neumann, C. Aeolian Sediment Transport. In Geomorphology of Desert Environments; University of Guelph: Guelph, ON, Canada, 2009.

30. Davidson-Arnott, R.; Ollerhead, J.; Hesp, P.A.; Walker, I.J. Spatial and Temporal Variability in Intensity of Aeolian Transport on a Beach and Foredune 2003. Available online: https://www.semanticscholar.org/ paper/SPATIAL-AND-TEMPORAL-VARIABILITY-IN-INTENSITY-OF-ON-Davidson-Arnott-Ollerhead/ c72d9f66c802cb33dbbbb64fb7b8056aac107696 (accessed on 25 November 2020).

31. Kok, J.F.; Parteli, E.J.R.; Michaels, T.I.; Karam, D.B. The physics of wind-blown sand and dust. Rep. Prog. Phys. 2012, 75, 106901. [CrossRef] [PubMed]

32. Bagnold, R.A. The movement of desert sand. Geogr. J. 1935, 85, 342-365. [CrossRef]

33. Zingg, A.W. Wind tunnel studies of the movement of sedimentary material: Soil Conservation Service, Manhattan, Kansas. In Proceedings of the 5th Hydraulic Conference, Iowa City, IA, USA, 17 August 1953.

34. Owen, P.R. Saltation of uniform grains in air. J. Fluid Mech. 1964, 20, 225-242. [CrossRef] 
35. van Rijn, L.C. Aeolian Transport Over a Flat Sediment Surface. Aeolian Transp. 2019. Available online: https: //www.leovanrijn-sediment.com/papers/Aeoliansandtransport2018.pdf (accessed on 25 November 2020).

36. Bauer, B.O.; Davidson-Arnott, R.G.D.; Hesp, P.A.; Namikas, S.L.; Ollerhead, J.; Walker, I.J. Aeolian sediment transport on a beach: Surface moisture, wind fetch, and mean transport. Geomorphology 2009, 105, $106-116$. [CrossRef]

37. Bauer, B.O.; Davidson-Arnott, R.G.D. A general framework for modeling sediment supply to coastal dunes including wind angle, beach geometry, and fetch effects. Geomorphology 2003, 49, 89-108. [CrossRef]

38. Davidson-Arnott, R.G.D. Instantaneous and Mean Aeolian Sediment Transport Rate on Beaches. J. Coast. Res. 2009, 56, 297-301.

39. Davidson-Arnott, R.G.D.; Yang, Y.; Ollerhead, J.; Hesp, P.A.; Walker, I.J. The effects of surface moisture on aeolian sediment transport threshold and mass flux on a beach. Earth Surf. Process. Landforms 2008, 33, 55-74. [CrossRef]

40. Ning, Q.; Li, B.; Ellis, J.T. Fence height control on sand trapping. Aeolian Res. 2020, 46, 100617. [CrossRef]

41. Bundesamt für Kartographie und Geodäsie (Federal Agency for Cartography and Geodesy). Geodaten der deutschen Landesvermessung. Bundesamt für Kartographie und Geodäsie (Federal Agency for Cartography and Geodesy), Leipzig, Germany. (C) GeoBasis-DE/ BKG (2020) Referring to the Licence Text. Available online: http://sg.geodatenzentrum.de/web_public/nutzungsbedingungen.pdf (accessed on 25 November 2020).

42. Landesamt für Geoinformation und Landesvermessung Niedersachsen. Auszug aus den Geodaten des Landesamtes für Geoinformation und Landesvermessung Niedersachsen. Landesamt für Geoinformation und Landesvermessung Niedersachsen, Germany. (C) dl-de/by-2-0 (2020) Referring to the Licence Text. Available online: www.govdata.de/dl-de/by-2-0 (accessed on 25 November 2020).

43. de Groot, A.V.; Oost, A.P.; Veeneklaas, R.M.; Lammerts, E.J.; van Duin, W.E.; van Wesenbeeck, B.K. Tales of island tails: Biogeomorphic development and management of barrier islands. J. Coast. Conserv. 2017, 21, 409-419. [CrossRef]

44. Reise, K. Coast of change: Habitat loss and transformations in the Wadden Sea. Helgol. Mar. Res. 2005, 59, 9-21. [CrossRef]

45. Oost, A.P.; Hoekstra, P.; Wiersma, A.; Flemming, B.; Lammerts, E.J.; Pejrup, M.; Hofstede, J.; van der Valk, B.; Kiden, P.; Bartholdy, J.; et al. Barrier island management: Lessons from the past and directions for the future. Ocean Coast. Manag. 2012, 68, 18-38. [CrossRef]

46. Hacker, E.; Johannsen, R. Ingenieurbiologie, 1. Aufl; UTB: Stuttgart, Germany, 2011; ISBN 9783838533322.

47. Thorenz, F. Coastal Flood Defence and Coastal Protection along the North Sea Coast of Niedersachsen; Die Küste (The Coast) No. 74. 2008. Available online: https://hdl.handle.net/20.500.11970/101601 (accessed on 25 November 2020).

48. Bundesamt für Seeschifffahrt und Hydrographie. Gezeitenkalender 2020. Hoch- und Niedrigwasserzeiten für die Deutsche Bucht und deren Flussgebiete; Bundesamt für Seeschifffahrt und Hydrographie No. 2117: Hamburg/Rostock, Germany, 2019; ISBN 978-3-86987-924-6.

49. Hayes, M.O. Barrier Island Morphology as a Function of Tidal and Wave Regime: Barrier Islands from the Gulf of St. Lawrence to the Gulf of Mexico; Academic Press: New York, NY, USA, 1979; pp. 1-27.

50. Niemeyer, H.D. Long Term Morphodynamical Development of the East Frisian Island and Coast. In Proceedings of the 24th International Conference on Coastal Engineering, Kobe, Japan, 23-28 October 1994.

51. Hagen, R.; Freund, J.; Plüß, A.; Ihde, R.; Validierungsdokument EasyGSH-DB Nordseemodell. Teil: UnTRIM2-SediMorph-UnK. Bundesanstalt für Wasserbau, Karlsruhe, Germany; 2019. Available online: https://doi.org/10.18451/k2_easygsh_1 (accessed on 25 November 2020).

52. Kottek, M.; Grieser, J.; Beck, C.; Rudolf, B.; Rubel, F. World Map of the Köppen-Geiger climate classification updated. METZ 2006, 15, 259-263. [CrossRef]

53. Deutscher Wetterdienst. Climata Data Center. Wind, Perception and Temperature. 2020. Available online: Ftp://opendata.dwd.de/climate_environment/CDC/ (accessed on 25 November 2020).

54. Niedersächsischer Landesbetrieb für Wasserwirtschaft, Küsten- und Naturschutz (Lower Saxony Water Management, Coastal Protection and Nature Conservation Agency). Documentation of the Configuration of the Installed Sand Trapping Fence on Langeoog; Niedersächsischer Landesbetrieb für Wasserwirtschaft, Küsten- und Naturschutz (Lower Saxony Water Management, Coastal Protection and Nature Conservation Agency): Lower Saxony, Germany, 2020. 
55. Sherman, D.J.; Swann, C.; Barron, J.D. A high-efficiency, low-cost aeolian sand trap. Aeolian Res. 2014, 13, 31-34. [CrossRef]

56. Campos, L.A.D. Quantification Methods for Aeolian Sand Transport on Beaches. Ph.D. Thesis, University of Twente, Enschede, The Netherlands, 2018.

57. Eijkelkamp Soil \& Water. Manual, Saltiphone. 2019. Available online: https:/en.eijkelkamp.com/products/ sensors-monitoring_uk/saltiphone.html (accessed on 25 November 2020).

58. Spaan, W.P.; van den Abeele, G.D. Wind borne particle measurements with acoustic sensors. Soil Technol. 1991, 4, 51-63. [CrossRef]

59. Goossens, D.; Nolet, C.; Etyemezian, V.; Duarte-Campos, L.; Bakker, G.; Riksen, M. Field testing, comparison, and discussion of five aeolian sand transport measuring devices operating on different measuring principles. Aeolian Res. 2018, 32, 1-13. [CrossRef]

60. Omega Engineering. Wind Monitor Stations: Product Specifications. Available online: https://in.omega.com/ pptst/WMS-20.html (accessed on 25 November 2020).

61. DJI Phantom 4 RTK. Product Specifications. Available online: https://www.dji.com/de/phantom-4-rtk/info (accessed on 25 November 2020).

62. Javad. Data Sheet GNSS Receiver Sigma-3. 2019. Available online: http://download.javad.com/manuals/ hardware/Sigma_Operators_Manual.pdf (accessed on 25 November 2020).

63. ISO. ISO 17892-4:2016 Geotechnical Investigation and Testing_Laboratory Testing of Soil_Part 4: Determination of Particle Size Distribution; German Version EN ISO 17892-4:2016; Beuth Verlag GmbH: Berlin, Germany, 2016.

64. DeltaT Devices. ML3 Soil Moisture Sensor. Product Specifications. 2020. Available online: https://www.ugtonline.de/ (accessed on 25 November 2020).

65. Namikas, S.L.; Bauer, B.O.; Sherman, D.J. Influence of averaging interval on shear velocity estimates for aeolian transport modeling. Geomorphology 2003, 53, 235-246. [CrossRef]

66. Vickers, D.; Mahrt, L. The Cospectral Gap and Turbulent Flux Calculations. J. Atmos. Oceanic Technol. 2003, 20, 660-672. [CrossRef]

67. Belly, P.Y. Sand Movement by Wind; Technichal Memorandum No. 1; US Army Corps of Engineers, Coastal Engineering Research Center: Washington, DC, USA, 1964.

68. Ellis, J.T.; Li, B.; Farrell, E.J.; Sherman, D.J. Protocols for characterizing aeolian mass-flux profiles. Aeolian Res. 2009, 1, 19-26. [CrossRef]

69. Nikuradse, J. Strömungsgesetze in Rauhen Rohren [Flow Laws in Rough Pipes]; NACA: Washington, DC, USA, 1950.

70. Vithana. The Effect of Stone Protrusion on the Incipient Motion of Rock Armour under the Action of Regular Waves. Ph.D. Thesis, University College London, London, UK, 2013.

71. Bergeron, N.E.; Abrahams, A.D. Estimating shear velocity and roughness length from velocity profiles. Water Resour. Res. 1992, 28, 2155-2158. [CrossRef]

72. Delgado-Fernandez, I. A review of the application of the fetch effect to modelling sand supply to coastal foredunes. Aeolian Res. 2010, 2, 61-70. [CrossRef]

73. Hoonhout, B.; de Vries, S. Field measurements on spatial variations in aeolian sediment availability at the Sand Motor mega nourishment. Aeolian Res. 2017, 24, 93-104. [CrossRef]

74. Shao, Y.; Lu, H. A simple expression for wind erosion threshold friction velocity. J. Geophys. Res. Space Phys. 2000, 105, 22437-22443. [CrossRef]

75. Han, Q.; Qu, J.; Liao, K.; Zhu, S.; Zhang, K.; Zu, R.; Niu, Q. A wind tunnel study of aeolian sand transport on a wetted sand surface using sands from tropical humid coastal southern China. Environ. Earth Sci. 2011, 64, 1375-1385. [CrossRef]

76. van Rijn, L.C.; Strypsteen, G. A fully predictive model for aeolian sand transport. Coast. Eng. 2020, 156, 103600. [CrossRef]

77. Poortinga, A.; Keijsers, J.G.S.; Maroulis, J.; Visser, S.M. Measurement uncertainties in quantifying aeolian mass flux: Evidence from wind tunnel and field site data. PeerJ 2014, 2, e454. [CrossRef] [PubMed]

78. Bauer, B.O.; Davidson-Arnott, R.G.D. Aeolian particle flux profiles and transport unsteadiness. J. Geophys. Res. Earth Surf. 2014, 119, 1542-1563. [CrossRef]

79. Dong, Z. Height profile of particle concentration in an aeolian saltating cloud: A wind tunnel investigation by PIV MSD. Geophys. Res. Lett. 2003, 30, 820. [CrossRef]

80. Bagnold, R.A. The size-grading of sand by wind. Proc. R. Soc. Lond. Ser. A Math. Phys. Sci. 1937, 163, $250-264$. 
81. White, B.R. Soil transport by wind on Mars. J. Geophys. Res. Space Phys. 2013, 4643-4651. [CrossRef]

82. Kawamura, R. Study on sand movement by wind. Rep. Inst. Sci. Technol. 1951, 5, 95-112.

83. Hsu, S.A. Coastal Studies Institute; Louisiana State University Baton Rouge; Louisiana 70803. Computing Eolian Sand Transport from Routine Weather Data. In Proceedings of the 14th International Conference on Coastal Engineering, Copenhagen, Denmark, 24-28 June 1974.

84. Durán, O.; Claudin, P.; Andreotti, B. On aeolian transport: Grain-scale interactions, dynamical mechanisms and scaling laws. Aeolian Res. 2011, 3, 243-270. [CrossRef]

85. Levin, N.; Ben-Dor, E.; Kidron, G.J.; Yaakov, Y. Estimation of surface roughness $\left(\mathrm{z}_{0}\right)$ over a stabilizing coastal dune field based on vegetation and topography. Earth Surf. Process. Landforms 2008, 33, 1520-1541. [CrossRef]

86. Gillies, J.A.; Etyemezian, V.; Nikolich, G.; Glick, R.; Rowland, P.; Pesce, T.; Skinner, M. Effectiveness of an array of porous fences to reduce sand flux: Oceano Dunes, Oceano CA. J. Wind Eng. Ind. Aerodyn. 2017, 168, 247-259. [CrossRef]

87. Strypsteen, G.; Montreuil, A.-L.; Rauwoens, P. Aeolian Sand Transport at the Belgian Coast: Field Campaigns and first Results. Coastal Dynamics. 2017. Available online: http://coastaldynamics2017.dk/onewebmedia/ 117_strypsteen.pdf (accessed on 25 November 2020).

88. Goossens, D.; Offer, Z.; London, G. Wind tunnel and field calibration of five aeolian sand traps. Geomorphology 2000, 35, 233-252. [CrossRef]

89. Poortinga, A.; van Minnen, J.; Keijsers, J.; Riksen, M.; Goossens, D.; Seeger, M. Measuring fast-temporal sediment fluxes with an analogue acoustic sensor: A wind tunnel study. PLoS ONE 2013, 8, e74007. [CrossRef] [PubMed]

90. van der Wal, D. Effects of fetch and surface texture on aeolian sand transport on two nourished beaches. J. Arid. Environ. 1998, 39, 533-547. [CrossRef]

91. van der Wal, D. The Impact of the Grain-Size Distribution of Nourishment Sand on Aeolian Sand Transport. J. Coast. Res. 1998, 14, 620-631.

Publisher's Note: MDPI stays neutral with regard to jurisdictional claims in published maps and institutional affiliations.

(C) 2020 by the authors. Licensee MDPI, Basel, Switzerland. This article is an open access article distributed under the terms and conditions of the Creative Commons Attribution (CC BY) license (http://creativecommons.org/licenses/by/4.0/). 